Etnográfica

Revista do Centro em Rede de Investigação em

Antropologia

vol. $22(2) \mid 2018$

Vol. 22 (2)

\title{
Dos dois lados do espelho: diálogos com um bairro cultural através da intervenção urbana
}

On both sides of the mirror: dialogues with a cultural quarter through urban intervention

\section{Pedro Costa e Ricardo Lopes}

\section{(2) OpenEdition}

Journals

Edição electrónica

URL: https://journals.openedition.org/etnografica/5572

DOI: 10.4000/etnografica.5572

ISSN: 2182-2891

\section{Editora}

Centro em Rede de Investigação em Antropologia

\section{Edição impressa}

Data de publição: 1 junho 2018

Paginação: 395-425

ISSN: 0873-6561

\section{Refêrencia eletrónica}

Pedro Costa e Ricardo Lopes, «Dos dois lados do espelho: diálogos com um bairro cultural através da intervenção urbana», Etnográfica [Online], vol. 22 (2) | 2018, posto online no dia 07 julho 2018, consultado o 20 janeiro 2022. URL: http://journals.openedition.org/etnografica/5572 ; DOI: https:// doi.org/10.4000/etnografica.5572

\section{(c) (i) (8)}

Etnográfica is licensed under a Creative Commons Attribution-NonCommercial 4.0 International License. 


\section{Dos dois lados do espelho: diálogos com um bairro cultural através da intervenção urbana}

\section{Pedro Costa e Ricardo Lopes}

As intervenções artísticas em bairros culturais podem ser uma boa forma de compreender as múltiplas camadas de usos, codificações e segregações que afetam estes espaços urbanos e que contribuem para a sua vitalidade quotidiana. Permitem também complementar e testar na prática muitos dos resultados obtidos pelos processos de investigação mais "convencionais" utilizados na pesquisa sobre esses territórios, possibilitando um diálogo a diferentes níveis com as comunidades locais e deslocando o foco das ferramentas conceptuais e analíticas do investigador para o próprio objeto de estudo. Os autores apresentam um conjunto de três intervenções urbanas que desenvolveram no Bairro Alto, em Lisboa, durante três anos consecutivos, em articulação com um programa de pesquisa sobre dinâmicas criativas em bairros culturais de diversas cidades, as quais lhes permitiram desenvolver novas heurísticas para a sua pesquisa e aprofundar a reflexão sobre o potencial da intervenção artística na relação com a comunidade e o conhecimento do território. Estas experiências exploraram abordagens participativas baseadas em diferentes disciplinas artísticas, permitindo testar um conjunto de ideias em relação às lógicas de apropriação do espaço, às dinâmicas de liminaridade e de conflito e à capacidade de vitalização urbana.

PALAVRAS-CHAVE: abordagens participativas, meios criativos, informalidade, bairros culturais, espaço público, intervenções artísticas.

On both sides of the mirror: dialogues with a cultural quarter through urban intervention - Artistic interventions in cultural quarters can be a good way to understand the multiple layers of uses, coding and segregation that affect these urban spaces and that contribute to their everyday vitality. Similarly, they enable us to complement and to test in practice many of the results obtained by more "conventional" research processes used in the study of these territories, allowing for a dialogue at different levels with local communities, and shifting the focus of the conceptual and analytical tools from the researcher to the own subject of study. The authors present a set of three urban interventions that they have developed in Bairro Alto, in Lisbon, during three consecutive years, in conjunction with a program of research on creative dynamics in cultural quarters of several cities. This program allowed them to develop new heuristics for their research and to further reflection on the potential of artistic intervention for the relationship with the community and knowledge of the territory. These experiences explored participatory approaches based on different artistic disciplines, enabling the testing of a set of ideas relating to the logics of space appropriation of, to the dynamics of liminality and conflict, and to the capability of urban revitalization. 
KEYWORDS: participatory approaches, creative milieus, informality, cultural quarters, public space, artistic interventions.

COSTA, Pedro (pedro.costa@iscte-iul.pt) - ISCTE - Instituto Universitário de Lisboa, Dinâmia'CET-IUL, Portugal.

LOPES, Ricardo (ricardovenanciolopes@gmail.com) - ISCTE - Instituto Universitário de Lisboa, Dinâmia'CET-IUL, Portugal.

INTRODUÇÃO:

AS ABORDAGENS PARTICIPATIVAS COMO FERRAMENTA

PARA A ANÁLISE DAS DINÂMICAS CRIATIVAS NO ESPAÇO URBANO

As intervenções artísticas na esfera pública podem ser uma boa forma de compreender os múltiplos estratos de uso e camadas de segregação que se encontram nos complexos organismos que são as cidades. ${ }^{1}$ Em particular, certas áreas urbanas, como os bairros culturais, apresentam um potencial acrescido para a análise destas dinâmicas. Com efeito, estes são normalmente bairros que se consubstanciam em contextos urbanos caracterizados por uma maior informalidade e abertura à diferença, os quais são preponderantes para a expressão da diversidade e da liminaridade, aspetos particularmente interessantes para as intervenções artísticas, caracterizadas muitas vezes pela transgressão, pela diferenciação e distinção e, também, portanto, no limite, pelo conflito (Costa e Lopes 2013, 2015). Pequenas iniciativas que se desenvolvem de uma maneira informal e efémera por artistas (ou investigadores...) que escolhem a cidade como palco para o seu trabalho, explorando as fronteiras ambíguas e flexíveis entre os espaços públicos e privados, podem ser particularmente interessantes. Elas permitem evidenciar a multiplicidade de acontecimentos e os habituais conflitos verificados em ambientes criativos, sendo igualmente importantes para equacionar a valorização dos aspetos mais vernaculares destes lugares e para colocar em causa ou em discussão perspetivas de aprofundamento dos processos de gentrificação ou de massificação cultural.

Este artigo apresenta um conjunto de práticas que permitiram aos autores discutir, no/com o terreno, esta relação entre intervenções urbanas, informalidade e apropriação de espaços da esfera pública, explorando a forma como

I Uma versão preliminar deste texto foi publicada como working paper (Costa e Lopes 2016), tendo o seu conteúdo sido igualmente apresentado em diversas conferências e seminários, nacional e internacionalmente. Os autores agradecem todos os comentários obtidos nessas apresentações, bem como os contributos dos pareceristas da Etnográfica que possibilitaram o refinamento do artigo para esta sua publicação definitiva. 
certas dinâmicas artísticas informais podem contribuir para a revitalização urbana e para o desenvolvimento de "verdadeiros" ambientes criativos que conservem a capacidade de fornecer genuinidade ou vernacularidade, sem cair na turistificação ou na mera mercantilização, material ou simbólica. É complementar a um outro artigo (Costa e Lopes 2017), no qual são explorados mais diretamente os efeitos ao nível do desenvolvimento urbano e das dinâmicas criativas resultantes das intervenções realizadas e as lógicas de apropriação da esfera pública e de conflito de interesses a elas associadas. Neste artigo, por seu lado, explora-se mais diretamente a questão da utilização destas metodologias e, mais em geral, o potencial das abordagens participativas centradas na intervenção urbana como ferramenta de pesquisa para a análise das dinâmicas criativas no espaço urbano.

São apresentadas e analisadas neste artigo três intervenções urbanas que exploraram abordagens participativas baseadas em diferentes disciplinas artísticas (fotografia, instalação, arquitetura, artes performativas, intervenção urbana), desenvolvidas no Bairro Alto, o "principal" bairro cultural de Lisboa, durante três anos consecutivos, em articulação com um programa de pesquisa mais amplo sobre dinâmicas criativas em bairros culturais de diversas cidades. Estas intervenções permitiram aos autores desenvolver novas heurísticas para a sua pesquisa e aprofundar a reflexão sobre o potencial da intervenção artística na relação com a comunidade e na coconstrução de conhecimento sobre o território.

Em setembro de 2010, no âmbito de um projeto de investigação então em curso sobre dinâmicas criativas e formas de governança urbana em diversas cidades (o projeto Creatcity), realizou-se a primeira destas pesquisas baseadas numa abordagem participativa. " "Espaços liminares" devolvia à cidade, através de uma exposição fotográfica, alguns dos resultados do trabalho de campo realizado nesse projeto de investigação, desenvolvido em três bairros culturais, em Lisboa, Barcelona e São Paulo, incluindo o próprio Bairro Alto. Mas, em simultâneo, pretendia explorar e testar os limites entre o espaço público e o privado, numa antiga loja devoluta há vários anos, reintroduzindo-a nas dinâmicas citadinas e criando um novo "spot" na esfera pública do bairro. Durante dez dias foi desenvolvida uma intervenção neste espaço abandonado e expectante, tematicamente centrada numa exposição fotográfica sobre a apropriação de espaço público em bairros culturais, mas focada igualmente em debates, concertos e outras demonstrações artísticas que permitiram, através do encontro

2 A análise aqui efetuada insere-se no quadro mais amplo da investigação desenvolvida pelos autores no âmbito do projeto "Creatcity - A governance culture for the creative city: urban vitality and international networks” (PTDC/AUR/65885/2006), no qual se estudam as raízes, as formas e a governança das “dinâmicas criativas" em diversos contextos urbanos em três cidades: Lisboa, Barcelona e São Paulo. Para mais informação sobre o projeto, consulte-se o site respetivo $-<$ http://creatcity.dinamia.iscte.pt/ > bem como Costa (2013). 
entre investigadores e público, não só apresentar resultados, mas também confrontá-los (e discuti-los) com os mesmos. Todas as intervenções desenvolvidas posteriormente viriam a seguir essa linha estratégica de articulação entre sociedade e academia, no sentido da promoção do diálogo com a comunidade acerca dos resultados obtidos no processo científico, mas também no sentido de um envolvimento do público e dos destinatários finais dos resultados da pesquisa na própria construção dos resultados do processo científico.

Em dezembro de 2011 foi desenvolvida a segunda intervenção artística em análise. "Bairros como nós", inserindo-se nas comemorações institucionais do aniversário do Bairro Alto, propunha mostrar e confrontar os seus utilizadores com dinâmicas similares às existentes no bairro sem nunca o evidenciar - utilizando fotografias de bairros "similares" (que os autores estavam a estudar em paralelo) em diferentes cidades: Barcelona, São Paulo, Istambul, Paris, Seattle, Florença, Copenhaga, São Francisco, Berlim e Londres. Coladas em 15 fachadas, explorando os limites difusos da "pele" dos edifícios, entre público e privado, as fotos criavam um percurso que surpreendia os utilizadores e transeuntes que caminhavam no bairro. A intervenção não tinha um período predefinido de duração ou de permanência nas paredes da cidade, jogando com as próprias noções de efemeridade e de informalidade. Além de explorar aspetos artísticos e estéticos nos limites entre público e privado, a exibição pretendia criar um sentido crítico nos observadores, que eram levados a pensar em dinâmicas e acontecimentos quotidianos do seu bairro (por exemplo, os conflitos associados à animação noturna, a questão da videovigilância, ou as dinâmicas informais de sociabilidade) a partir de uma perspetiva diferente (ou, por vezes, nem tanto...) daquela a que estavam habituados.

Em dezembro de 2012 realizou-se a última intervenção desta série aqui em análise, intitulada "Beyond visible". O happening, que seguia os conceitos explorados nas intervenções anteriores (como as relações entre espaço público vs. espaço privado, ou público vs. artwork), tinha como conceito-chave explorar a ideia dos diferentes layers de codificação existentes nos ambientes criativos, neste caso apenas a partir da realidade específica do Bairro Alto. Assim, ao longo de uma noite, os transeuntes que caminhavam pela rua eram convidados a entrar no espaço mobilizado para o efeito (novamente um espaço "em transição", a aguardar licenciamento camarário) e a "construir" a sua própria exposição, através do seu percurso individual por um espaço de descoberta, semiocultado, mas aberto a todas as pessoas ou práticas. Ao longo da exibição, os visitantes eram surpreendidos por várias intervenções artísticas, de diversos tipos, que culminavam no seu próprio envolvimento como objeto fotográfico, passando dessa forma a fazer parte da intervenção artística - não só como espectador e elemento participante, mas também como objeto exibido.

Se, por um lado, estas intervenções artísticas efémeras introduziram na cidade novos espaços de uso público, em locais públicos e/ou privados trazidos 
para a esfera pública, e criaram "novas" zonas que voltaram a ganhar uma utilidade (mais ou menos temporária) na cidade, contribuindo para a vitalidade e centralidade simbólica da área, por outro lado, as intervenções realizadas permitiram complementar e testar na prática muitos dos resultados obtidos pelos processos de investigação mais "convencionais" utilizados na pesquisa sobre esses espaços urbanos, possibilitando um diálogo a diferentes níveis com as comunidades locais e deslocando o foco das ferramentas conceptuais e analíticas do investigador para o próprio objeto de estudo.

As abordagens participativas artísticas são aqui entendidas como uma forma de construção de conhecimento que operacionaliza metodologias de terreno que envolvem processos de criação estética em que os investigadores e as pessoas que, do ponto de vista "tradicional", constituem os "objetos" da pesquisa, cooperam entre si para a construção e teste dos resultados do próprio corpo da investigação. O processo epistemológico não está aqui, portanto, e contrariamente ao que ocorre tradicionalmente, centrado sobretudo no investigador e nos quadros teórico-analíticos por este mobilizados; os sujeitos da investigação assumem uma maior relevância, esbatendo-se as tradicionais assimetrias nestes papéis e assumindo-se formas mais equilibradas de construção de conhecimento. $\mathrm{O}$ veículo da criação (e da, muitas vezes indistinta, fruição) artística, permitindo a cooperação entre "investigadores" e "objetos" da pesquisa, possibilita explorar a experiência urbana e as consequências/causas das dinâmicas urbanas associadas a essa mesma intervenção artística de forma inovadora, procurando obter resultados dificilmente alcançáveis com abordagens mais "clássicas".

Tendo em conta este quadro geral, após uma breve contextualização deste trabalho à luz da problemática das dinâmicas criativas nos bairros culturais, e no Bairro Alto em particular, que se realiza na próxima secção, são depois analisadas mais em detalhe as três intervenções artísticas realizadas, refletindo sobre os seus objetivos, resultados e impactos, para por fim serem enunciadas algumas ilações a extrair destas experiências e apontadas algumas potencialidades e desafios destas abordagens para o conhecimento das dinâmicas urbanas e para o planeamento urbano.

O ENQUADRAMENTO DA PESQUISA:

AS DINÂMICAS CRIATIVAS NOS BAIRROS CULTURAIS, O CONFLITO E A INFORMALIDADE COMO MOTORES DA VITALIDADE ARTÍSTICA E DA REVITALIZAÇÃO URBANA

A investigação aqui apresentada desenvolveu-se num quadro mais amplo de pesquisa, que tem preocupado os autores deste artigo nos anos mais recentes, em torno da relação entre bairros culturais, "meios criativos", espaço púbico e intervenções artísticas, ou ainda do conflito e informalidade como motores 
da vitalidade artística e revitalização urbana (cf. Costa 2007, 2008, 2009, 2012, 2013, 2015; Costa et al. 2008; Costa e Lopes 201 1, 2013, 2015; Costa, Vasconcelos e Sugahara 2011 ; Lopes 2012, 2015).

Certos bairros, um pouco por todo o mundo, têm a capacidade de se afirmar como centros da criatividade e da vida cultural das cidades onde se encontram (Scott 2000; Costa et al. 2008). Estes "bairros criativos" são zonas onde fervilha a oferta cultural e artística, da mais "convencional" à mais "alternativa", mas são também espaços de encontro e sociabilidade, de grande vitalidade urbana, onde a arte e a cultura estão normalmente associadas à boémia e à vida noturna (O'Connor e Wynne 1996; Scott 2000; Costa 2007; Cooke e Lazzeretti 2008).

Os bairros culturais caracterizam-se por uma atmosfera "criativa" e uma aura simbólica particularmente interessante para discutir as questões da vitalidade artística. Independentemente da sua diversidade quanto às origens e características (Bell e Jayne 2004), apresentam um conjunto de fatores que os determinam e contribuem para a sua vitalidade. A diversidade e complexidade destes sistemas territoriais é muitas vezes apontada como base para a sua resiliência e para a capacidade de desenvolverem mecanismos de governança específicos e atributos simbólicos próprios que contribuem para a sua sustentabilidade (cf. Scott 2000; Costa 2007, 2012, 2013; Costa e Lopes 2013, 2015). Muitas vezes localizados em zonas históricas e/ou funcionalmente obsoletas das cidades, mas com um potencial de (re)afirmação simbólica e material bastante acentuado, desenvolvem-se de forma essencialmente informal e pouco planeada, articulando diferentes usos e utilizadores. Os espaços da esfera pública tornam-se os locais privilegiados para a tensão e conflitos tão característicos de territórios marcados por usos, ritmos e tempos tão díspares entre si (cf. Costa e Lopes 2015). A esfera pública assume-se, frequentemente, como espaço liminar, marcado pela transgressão e pela expressão (social e individual) do self, que vê nestes territórios locais importantes de (auto)afirmação dentro dos meios artísticos. Tornam-se assim importantes para a produção e fruição artística, as quais até, em grande parte dos casos, podem já não se desenvolver nestes locais (Costa e Lopes 2011), continuando contudo estes territórios a assumir-se como importantes nós de convivialidade e sociabilidade, vitais para a construção de reputação, legitimação e para mecanismos de gatekeeping (Becker 1982; DiMaggio 1987; Caves 2002; Borges e Costa 2012; Costa 2012) nos respetivos mundos da arte e em cenas culturais mais ou menos específicas (cf., para o caso do Bairro Alto, Costa 2015). Diferentes interesses e motivações geram os tradicionais conflitos de uso verificados nestas áreas, a vários níveis, entre utilizadores e residentes, utentes diurnos/noturnos, residentes tradicionais/recentes (incluindo new gentrifiers), atividades culturais tradicionais/novas, mas também, naturalmente, os decorrentes da atividade criativa em si mesma, a qual é transgressora por natureza (Costa 2007, 2008; Costa e Lopes 2013, 
2015). Contudo, são esses conflitos que permitem retardar os processos de gentrificação em territórios que, devido às suas características e centralidade, se tornam rapidamente alvo de processos de recomposição social e de transformação profunda ao nível das suas atividades económicas, mantendo-os assim mais próximos das suas características identitárias mais propícias às dinâmicas culturais e criativas (Costa e Lopes 2013, 2015).

São territórios que, pela sua diversidade e abertura, se tornam tradicionalmente mais cosmopolitas, tolerantes (e, portanto, abertos à liminaridade e a menores níveis de controlo social) e onde dinâmicas informais ganham espaço para se desenvolverem, gerando espaço para novas possibilidades criativas, não raramente longe dos principais espartilhos e lógicas comerciais e económicas. A esfera pública, nomeadamente aquela situada na negociação e intermediação entre o público e o privado, território de limites muito difusos e díspares na sociedade atual ( $c f$. Lopes 2012), torna-se a arena privilegiada para este tipo de intervenções, contribuindo para a forte identidade local destes bairros.

Estas dinâmicas, aqui brevemente enunciadas, permitem-nos entrever a relação entre bairros culturais, esfera pública e "meios criativos", em particular o papel do conflito e informalidade como motores da vitalidade artística, e podem ser apreendidas com um pouco mais de detalhe em Costa e Lopes (2017: secção 2). Da mesma, forma, e como pode ser também visto no mesmo artigo (secção 3), a própria evolução das lógicas de intervenção artística na esfera pública propiciou um maior potencial de utilização destas intervenções nestes contextos territoriais. À medida que as práticas artísticas foram abandonando as fortalezas da arte sacralizada e se foram aproximando de um trabalho mais próximo da matéria urbana, e mesmo crescentemente dialogante com ela, no seio de diversas correntes artísticas, esse papel ficou crescentemente facilitado (cf. Costa e Lopes 2017) e as intervenções urbanas na esfera pública foram-se propiciando como sujeitos ativos para uma reflexão como aquela a que nos propomos neste texto.

Neste quadro, e antes de avançarmos, importam umas breves palavras sobre o contexto territorial das experiências efetuadas. Com efeito, o caso do Bairro Alto, em Lisboa, é bem paradigmático da realidade acima enunciada, como temos tido oportunidade de defender ( $c f$., por exemplo, Costa 2007, 2008, 2009, 2013, 2015; Costa e Lopes 2011, 2013, 2014, 2015). Desde as suas origens no século XVI, quando representou a expansão da cidade para fora das antigas muralhas, o Bairro Alto tem-se afirmado e mantido como um espaço de transgressão e de informalidade, apesar de todas as suas mutações e reconfigurações, articulando-se sempre com o lado mais institucional do adjacente Chiado (originalmente dentro das muralhas), marcando durante séculos o panorama artístico lisboeta (Costa 2007, 2008; Costa e Lopes 2015).

O Bairro Alto, que se "afirma" e torna mais visível como bairro cultural nos anos 80 do século passado, encontra-se atualmente num claro processo de 
gentrificação e massificação (cf. Costa 2007, 2013, 2015; Costa e Lopes 2015), à imagem aliás do que se passou em outros bairros culturais por todo o mundo (cf. Costa e Lopes 2013). A crescente valorização simbólica do bairro por uma população mais massificada e o fenómeno de forte turistificação emergente em Lisboa nos anos mais recentes têm contribuído para uma alteração e "mainstreamização" desta zona da cidade, que se encontra numa clara sobrecarga de públicos, audiências e utilizadores ( $c f$. Costa 2013). O sistema produtivo local encontra-se em permanente renovação e reinvenção (desde há décadas, numa lógica de crescente diversidade dos sistemas de produção e consumo cultural), sendo atualmente um bairro mais orientado para o consumo cultural (lojas de design e imagem alternativa, consumo esteticizado e animação noturna) do que para a produção e criação, bem como um importante nó de convivialidade (Costa 2007, 2013, 2015; Costa e Lopes 2015). As suas características morfológicas, urbanísticas e tipológicas, bem como os conflitos de uso e externalidades negativas verificadas (ruído, falta de estacionamento, congestionamento rodoviário, entre outras) têm contribuindo para um certo controlo e abrandamento do processo de gentrificação ( $c f$., por exemplo, Costa e Lopes 2015; Costa 2013). Contudo, a diversidade de residentes, utilizadores e atividades, que se encontram em constante alteração ao longo do dia, contribuindo para o ambiente heterogéneo e tolerante do bairro, tem vindo a ser desafiada nos últimos anos, com potenciais impactos para a atividade cultural. O claro aumento do preço do solo tem sido traduzido em impactos sociais e económicos como a substituição de residentes e atividades, acompanhada por uma saída relativa da parte dos atores criativos que se expandem territorialmente para áreas envolventes, como São Paulo, Cais do Sodré ou o Intendente (Lopes 2015; Costa 2015).

Apesar das alterações que se têm verificado, o Bairro Alto mantém-se como local de produção/exibição artística fundamental na cidade de Lisboa e como nó de convivialidade de extrema importância para o processo artístico em Portugal. As suas características próprias, bem como o interesse que estas têm há anos levantado à investigação desenvolvida pelos autores, conduziram a que este território fosse imediatamente escolhido como arena para a experimentação dos processos de criação artística/investigação analisados neste trabalho.

\section{INTERVENÇÕES E APROPRIAÇÕES ARTÍSTICAS EFÉMERAS: TRÊS CASOS EM ANÁLISE}

Na sequência da análise continuada dos "meios criativos" e dos bairros culturais, resumidamente enunciada na secção anterior, os autores sentiram a necessidade de explorar abordagens participativas, baseadas em diferentes disciplinas artísticas (fotografia, instalação, arquitetura, artes performativas, intervenção urbana), com o objetivo de testar um conjunto de ideias em 
relação às lógicas de apropriação do espaço, às dinâmicas de liminaridade e de conflito, e à capacidade de vitalização urbana, associadas à intervenção artística em espaço urbano.

Um ponto de partida natural foi a adoção de abordagens site-specific, balizadas nos movimentos vanguardistas dos anos 60, primeiro desenvolvidas em espaços convencionais de exibição por artistas como Robert Morris ou em performances e happenings desenvolvidos em espaços informais da cidade por Allan Kaprow ou grupos como os Fluxus, abordagens que, pensadas para o local de intervenção, permitiam confrontar e estudar dinâmicas e ritmos estabelecidos no território (Traquino 2010; Lopes 2012; Costa e Lopes 2013). Interrogando e provando reações em residentes e utilizadores, estas atuações contribuíram decisivamente para ir inserindo na cidade novos espaços de uso público, tanto públicos como privados, que se tornaram espaços da esfera pública, mesmo que por apenas alguns dias ou horas, contribuindo para o mix de happenings quotidianos.

As três intervenções em análise, estabelecendo-se longe dos tradicionais cânones de mediação artística e dos espartilhos do licenciamento e das restrições municipais, permitiram uma abordagem diversa daquela decorrente de dinâmicas culturais e académicas mais "institucionalizadas" e assim fomentar a discussão em torno dos temas em estudo.

O contexto de pesquisa continuada nesta zona da cidade facilitou a realização de abordagens site-specific, enraizadas no território, que "provocassem" os residentes e utilizadores do Bairro Alto a fazer parte da experimentação. O envolvimento e a discussão com stakeholders locais, em particular relacionados com as comemorações "oficiais" dos $498 .^{\circ}$ e $499 .^{\circ}$ anos do Bairro Alto, promovidas pela Câmara Municipal de Lisboa (CML) e pela Associação de Comerciantes do Bairro Alto (ACBA), no contexto das quais os investigadores se envolveram, a par de múltiplas outras entidades, permitiram um quadro institucional favorável à implementação de uma lógica de pesquisa participativa em que investigador e objeto de investigação se articularam num território de experimentação comum.

\section{"Espaços liminares"}

A intervenção "Espaços liminares" marcou o início desta série de intervenções exploratórias. ${ }^{3}$ Foram as premissas relatadas anteriormente que levaram os autores, em setembro de 2010, no âmbito do projeto de pesquisa Creatcity, a não desenvolverem "apenas" uma "tradicional" exposição de fotografia (com

3 Mais informação em < http://espacosliminares.blogspot.pt/ > (última consulta em junho de 2018). "Espaços liminares" foi realizado no âmbito do projeto Creatcity, no Bairro Alto em setembro de 2010 , e em novembro do mesmo ano na Gràcia, em Barcelona. Autores: Ana Roldão, Cristina Latoeira, Pedro Costa, Ricardo Lopes e Samuel Dias. 
o objetivo de lhes permitir devolver alguns dos resultados da sua pesquisa à comunidade) e partirem para uma intervenção artística na cidade, trazendo para a esfera pública, de forma mais complexa, trabalhos que tradicionalmente se mantêm no meio académico e realizando a primeira abordagem participativa em análise, dando assim continuidade ao seu objeto de estudo.

"Espaços liminares" pretendia explorar os limites entre o espaço público e o privado de uma antiga loja fechada há vários anos, reintroduzindo-a nas dinâmicas urbanas e criando um novo "spot" na esfera pública do bairro. Em paralelo com a exposição fotográfica, resultante da pesquisa decorrente de uma abordagem visual ( $c f$. Costa e Lopes 2015) sobre a apropriação do espaço público em bairros culturais, foram desenvolvidos, ao longo de dez dias, debates, concertos e outras manifestações artísticas. Previam-se na programação três debates ("O futuro do Bairro Alto"; "Espaço público e criatividade", e "Olhar os bairros criativos - encontro com os fotógrafos"); contudo, ao longo dos dias e de modo informal, o debate alastrou e alargou-se, entre conversas, a diversos participantes da intervenção. Os Lama protagonizaram, através de uma performance criada para o efeito, a banda sonora para a inauguração. Pela intervenção passaram ainda, durante outros dias, os Pinto Ferreira e o DJ MD Azevedo, entre outros que, sem "aviso prévio", se atreveram a tocar no sofá do espaço. Uma foto de grandes dimensões, colada numa das paredes do espaço intervencionado, foi deixada à apropriação de curiosos e de artistas que a reinterpretaram e transformaram de uma forma livre e espontânea, dando uso às tintas, pincéis e sprays disponibilizados.

As fotografias eram representativas de espaços da esfera pública, do Bairro Alto, da Gràcia, em Barcelona, e da Vila Madalena, em São Paulo, e das múltiplas formas como estes espaços são apropriados, marcados e experienciados pelas diversas camadas sociais que os vivem e usam quotidianamente. Libertos de grandes espartilhos estéticos ou formais, cada um dos cinco fotógrafos procurou dar a sua leitura pessoal sobre a vivência e a transformação destes bairros a partir dos seus espaços públicos, e sobre como eles serão ou não (ainda?) a expressão da criatividade artística e da vitalidade urbana em cada uma daquelas três metrópoles.

O ponto de partida para o projeto foi o local onde este se iria desenvolver e o modo como este iria interagir com esta zona da cidade. Após um levantamento de diversos espaços "expectantes" para uma possível intervenção, desde apartamentos para aluguer a antigos espaços comerciais (entre eles uma farmácia, um talho, uma taberna), optou-se por utilizar um espaço expectante de licença de restauração (onde posteriormente pudemos encontrar um restaurante de cozinha de autor), algo na altura relativamente raro no Bairro Alto, por se encontrarem "congeladas" as licenças há vários anos (e serem rapidamente transacionadas as existentes). Localizado junto a uma das entradas mais importantes do bairro, no extremo sul da rua do Norte, permitiria que os transeuntes 
que entrassem no bairro, a partir da praça Luís de Camões (conhecida como "Largo do Camões"), fossem "convidados" a fazer parte da intervenção. O edificado de arquitetura pombalina encontrava-se à época em elevado estado de degradação. Após contactar o proprietário e explicar-lhe que gostávamos de desenvolver uma intervenção que não degradaria o seu imóvel, e que até, pelo contrário, poderia contribuir para a sua revitalização e criação de valor, mesmo que de forma temporária, ele aceitou apoiar a intervenção artística.

As características arquitetónicas do interior do edifício, apesar de preservadas nos pisos superiores, encontravam-se bastante alteradas no piso térreo, onde se desenvolveu a intervenção. O espaço servia à época de armazém de materiais de construção civil da empresa detentora do imóvel, enquanto aguardava por licenciamento camarário para iniciar as obras de remodelação do que viria a ser posteriormente uma estrutura para habitações de curta duração. O piso térreo, de elevado pé-direito, oferecia uma imagem "congelada" entre o passado e o futuro do que viria a ser aquele edifício. Assim, à semelhança de intervenções site-specific, os autores propuseram-se desenvolver uma intervenção adaptada ao espírito do lugar, tendência que nos últimos anos tem sido explorada por equipas de criativos, não só com fins artísticos, para a reconversão de inúmeros espaços expectantes por todo o mundo ( $c f$. Lopes 2012).

A janela, de consideráveis dimensões na fachada, permitia que o interior estivesse em constante contacto com o exterior, contribuindo para criar curiosidade nas pessoas que circulavam na rua e gradualmente decidiam "invadir" aquele "tradicional" espaço privado e participar na exposição construída com andaimes e antigas portas que se encontravam armazenadas no interior da loja. Estes eram andaimes que aguardavam o começo das obras de recuperação do edificado e antigas portas que outrora dividam os espaços de habitação; tinham chegado ao final do seu ciclo naquele imóvel, visto que não iriam ser utilizadas no novo projeto, e ganharam uma nova função no período expositivo. Uma zona com sofás, algumas cadeiras e uma antiga televisão simulava um cenário de um "lar", uma casa que dava as boas vindas a quem olhava para dentro pela janela, num sentido claro de invasão de privacidade, convidando os "passantes" a decidirem juntar-se às discussões diárias que existiam no local sem qualquer tipo de formalidade. O som de fundo da performance musical que os Lama desenvolveram de uma forma espontânea, com ritmos e sons do bairro, sem grande ensaio ou programação, no dia da inauguração (e cuja gravação se reproduzia em loop nos dias seguintes), emanava para a rua, explorando o conceito de limite, entre interior e exterior, que em muitos casos pode não ser quebrado apenas de forma física mas através de sons, luzes, cheiros, por alguma coisa que de certa forma altere as características dos espaços, internos ou exteriores.

Ao longo dos dias, a permeabilidade e as barreiras foram diminuindo e a rua, a tradicional sala de estar do Bairro Alto, perante a ausência de espaços 


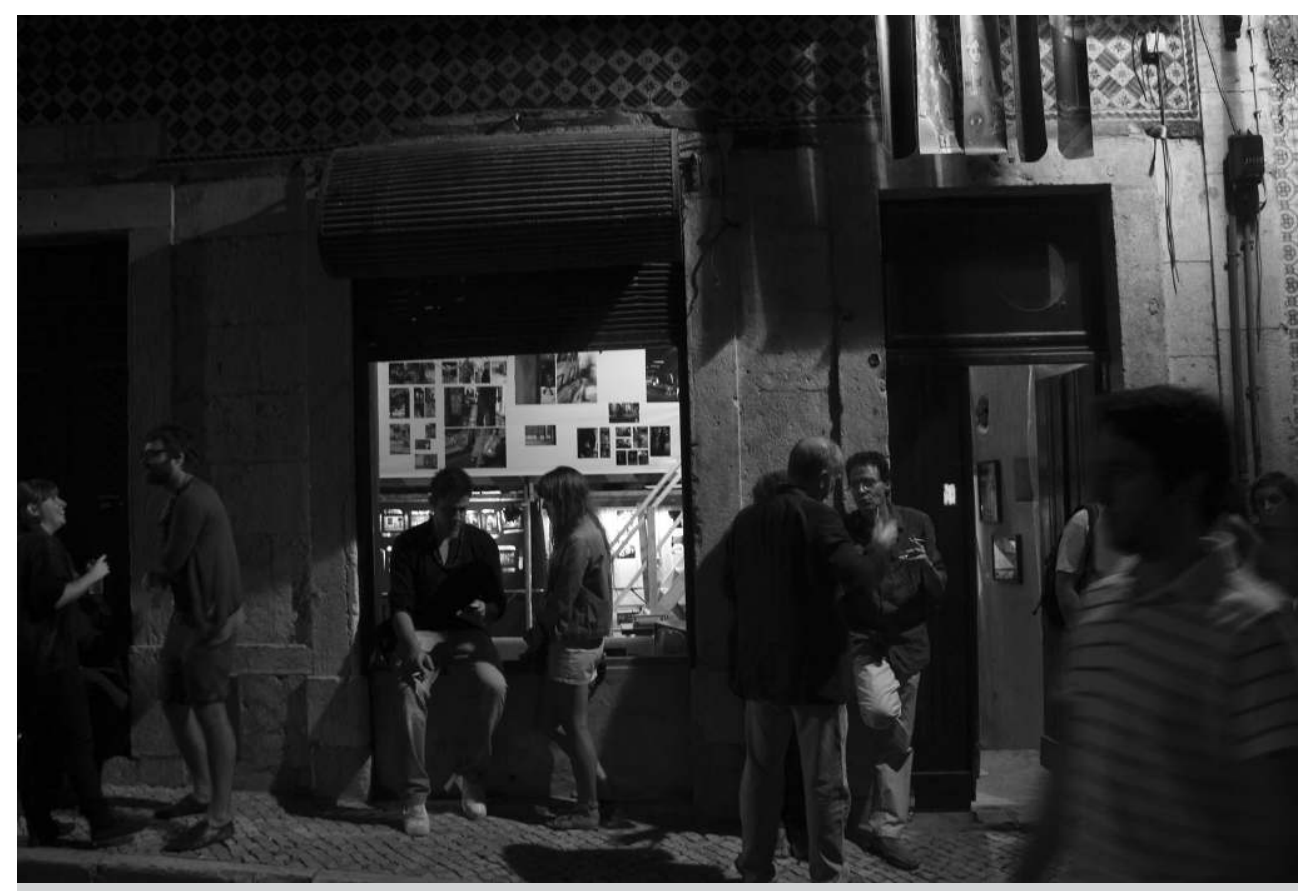

Figuras 1 a 8 - Intervenção "Espaços liminares" (Bairro Alto, rua do Norte, setembro de 2010).

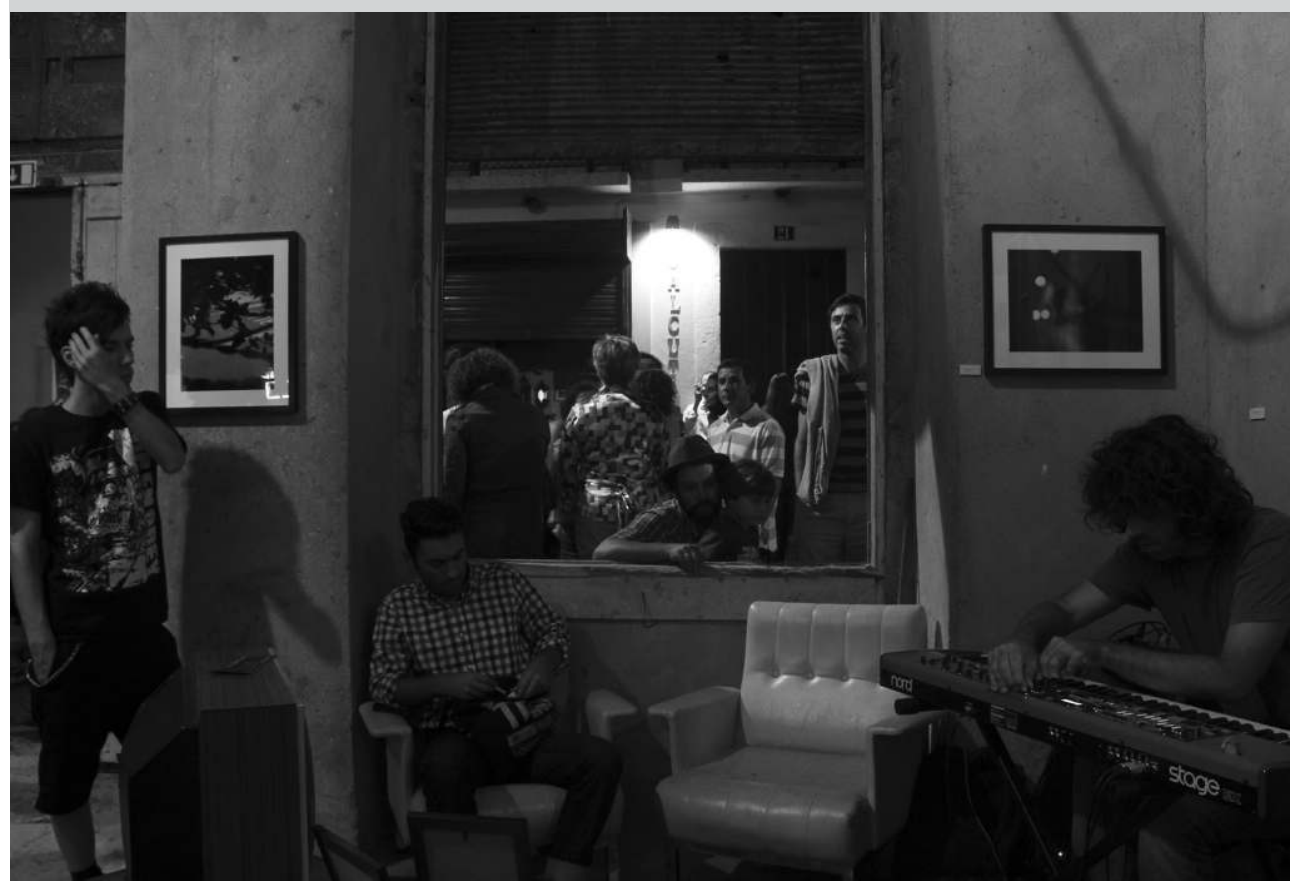




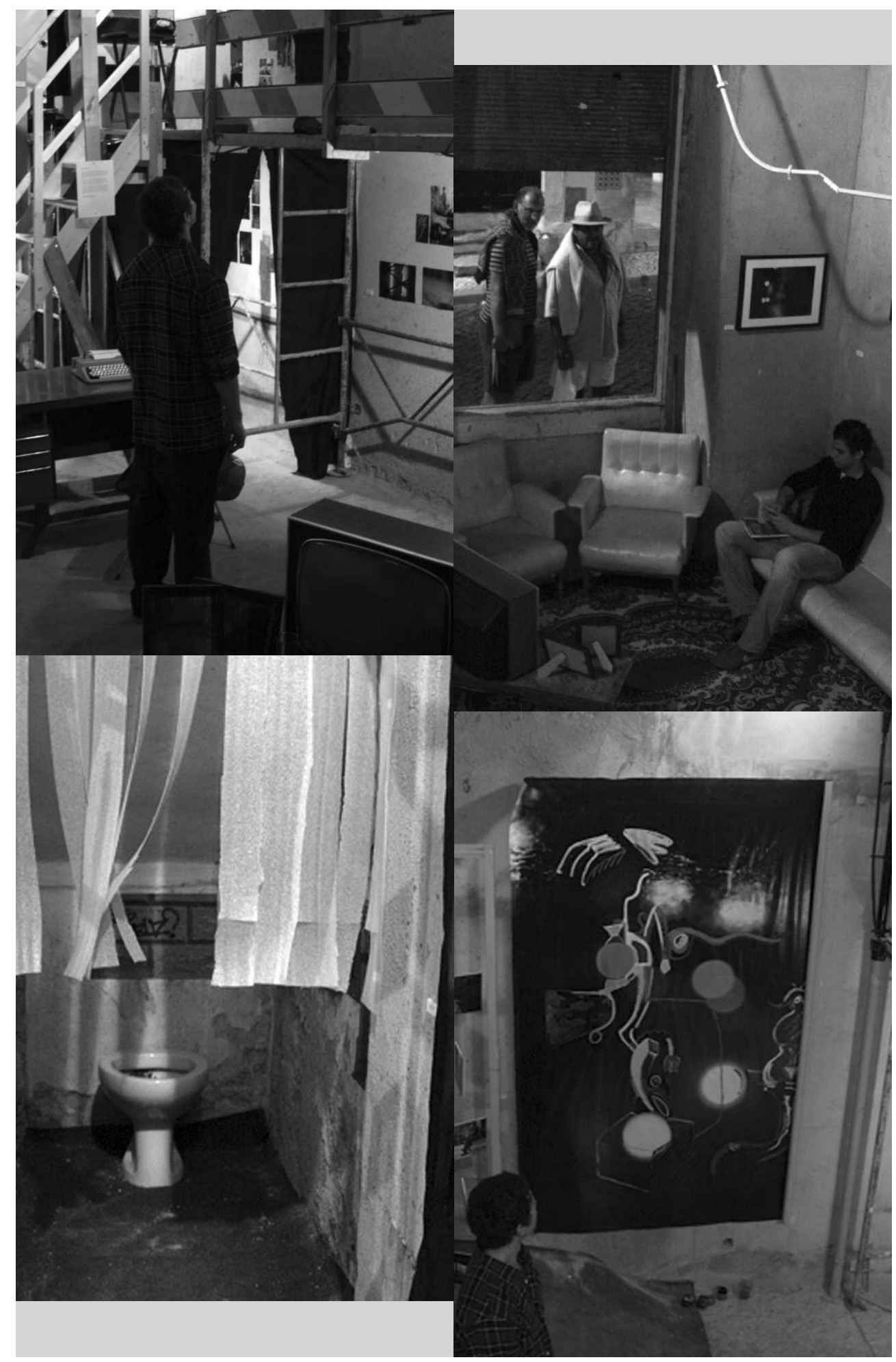



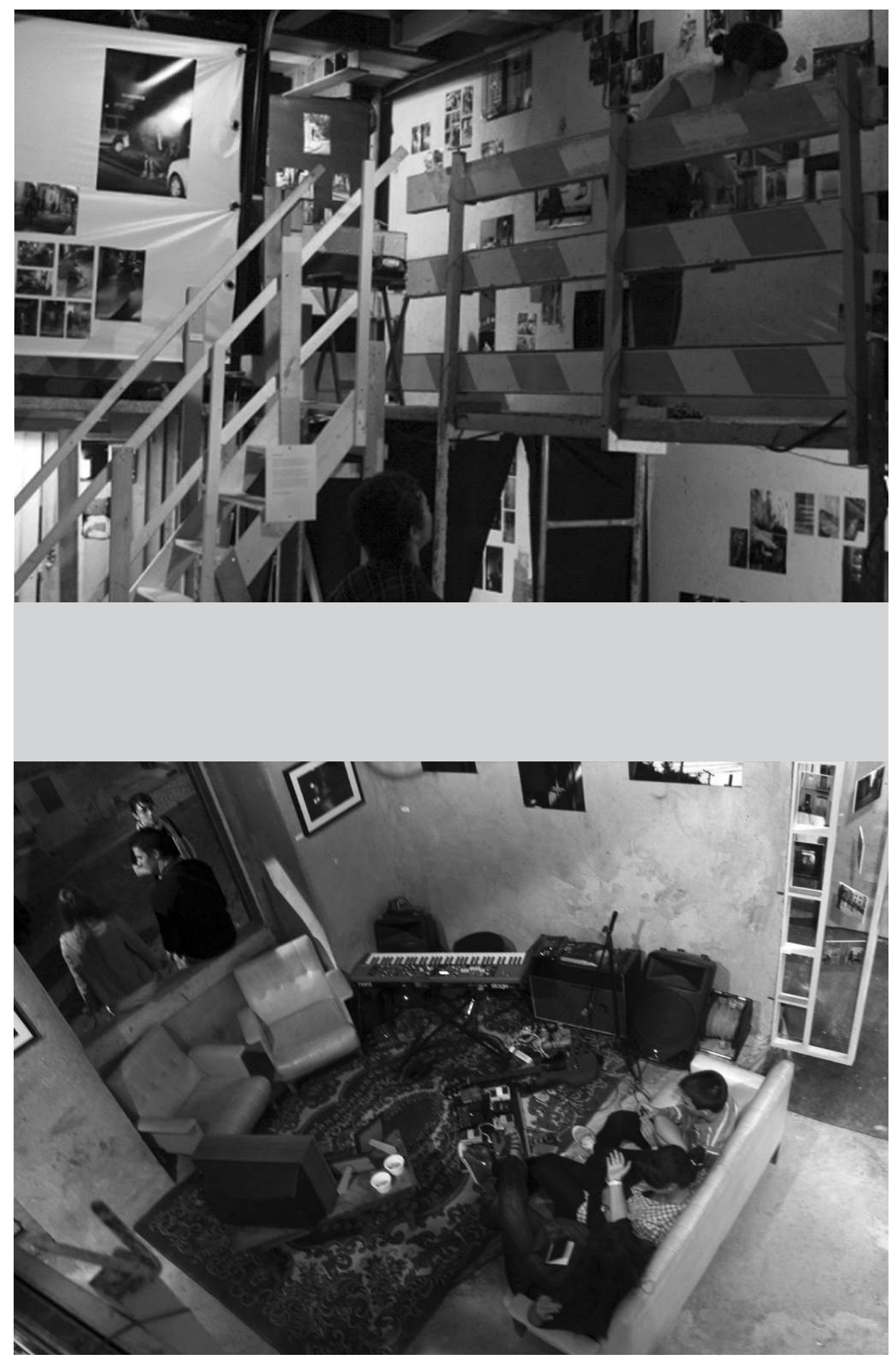
de estar dimensionados à escala das pessoas que acorrem ao bairro, invadiu e acoplou o espaço da intervenção, passando este a pertencer à esfera pública da cidade.

\section{"Bairros como nós"}

$\mathrm{Na}$ sequência dos conceitos desenvolvidos em "Espaços liminares" e em continuidade com o trabalho levado a cabo pelos autores, em dezembro de 2011 foi desenvolvida a segunda intervenção artística. "Bairros como nós" propunha mostrar aos utilizadores do Bairro Alto dinâmicas similares às nele verificadas, sem nunca mostrar o bairro - utilizando fotografias de bairros "criativos" em diferentes cidades, um pouco por todo o mundo: Gràcia (Barcelona), Vila Madalena (São Paulo), Beyoglu (Istambul), Marais (Paris), Capitol Hill (Seattle), Oltrarno (Florença), Indre By e Norrebro (Copenhaga), Haights e Russian Hill (São Francisco), Kreuzberg SO 36 (Berlim) e Brick Lane (Londres). ${ }^{4}$ Coladas em 15 fachadas, explorando os limites difusos da "pele" dos edifícios, entre público e privado, as fotos de grande dimensão $(2 \mathrm{~m} \times 1,3 \mathrm{~m})$ criavam um percurso que surpreendia os utilizadores e transeuntes que caminhavam no bairro. ${ }^{5}$

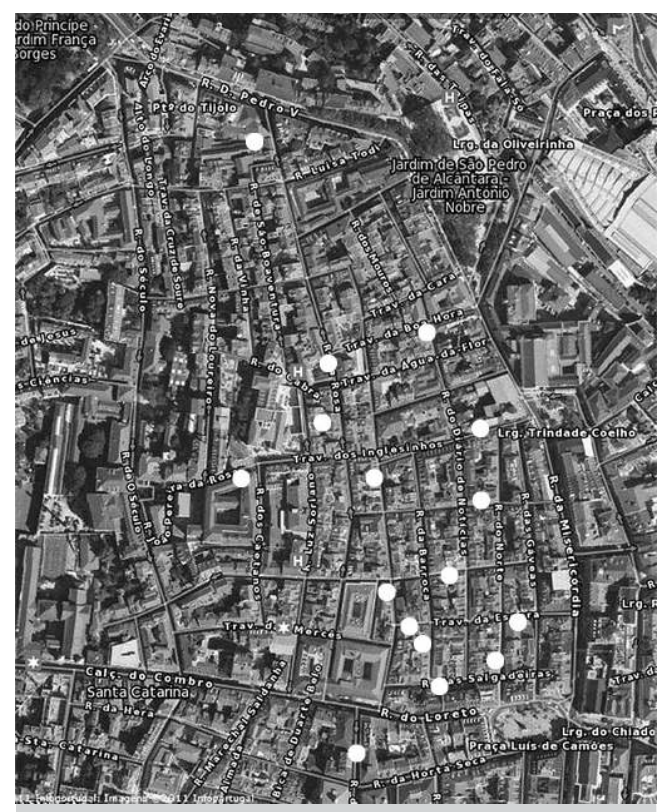

Figura 9 - Intervenção "Bairros como nós": localização das imagens em grande formato espalhadas por fachadas do Bairro Alto (dezembro de 2011).

4 Mais informação em < http://bairroscomonos.blogspot.pt/> (última consulta em junho de 2018). As fotografias foram realizadas no âmbito de abordagens fotográficas que os autores levaram a cabo em diferentes bairros "criativos" e boémios, em articulação com a análise efetuada no âmbito de um programa mais vasto (Costa e Lopes 2013).

5 A impressão das fotografias e demais materiais expositivos foi apoiada pela Associação de Comerciantes do Bairro Alto e pelo Dinâmia'CET-IUL. Esta exposição ao ar livre foi complementada por uma outra, realizada em paralelo, sobre o mesmo tema (pelos mesmos autores, ao mesmo tempo, num espaço de exposições mais convencional - a Casa da Imprensa, também nas imediações do Bairro Alto). No entanto, nenhuma referência explícita foi feita em cada uma destas imagens ao ar livre para essa exposição, nem para as outras fotos dessa intervenção urbana, as quais foram dispostas em certas paredes, a fim de que fossem encontradas "aleatoriamente" pelos passantes. Nesse mesmo espaço mais "convencional" foi ainda organizado um evento mais "académico" em torno da temática (conferência "Bairros como nós”, com R. Lopes, C. Latoeira, S. Dias, J. Seixas, W. Rodrigues e R. Campos, organizada pelo Dinâmia'CET-IUL, na Casa da Imprensa, Lisboa, 16 de dezembro de 2011 ). 
A intervenção desenvolveu-se num bairro onde desde 2008 estavam a ser aplicadas medidas de "higienização" e tinham sido "apagadas" ou "limpas" diferentes camadas de graffitis (bem como de cartazes difusores de informação), incluindo alguns trabalhos de autores de reconhecido nome internacional no campo da street art (Campos 2007), que marcavam a imagem desta zona da cidade. Esta é também a zona onde, em contraponto, foi na altura criada a primeira intervenção da Galeria de Arte Urbana por parte da CML, que pretendia criar uma galeria de street art em espaços institucionalizados e ao ar livre na cidade (veja-se, a este respeito, Costa e Lopes 2014).

Foi nesse contexto que os autores propuseram explorar a temática da legitimação e reputação associadas a uma nova mercantilização da arte que acontece no espaço público (Costa e Lopes 2015), após o convite da organização do "Dia do Bairro Alto" (iniciativa comemorativa do aniversário do estabelecimento do Bairro, neste caso, do seu $498 .^{\circ}$ aniversário, dinamizado por uma task force mobilizada pela associação de comerciantes local e algumas entidades municipais), que lançou o repto a diversos artistas para intervirem de diferentes formas culturais (cada artista era livre para desenvolver a proposta que entendesse) nesta zona da cidade. Procurou-se com a intervenção proposta pelos autores questionar o limite público/privado de uma fachada e os processos de legitimação associados às intervenções artísticas, bem como suscitar o sentido crítico dos utilizadores do bairro através da arte, tanto quanto ao modo de intervenção como à mensagem do objeto exposto, que remetia para o confronto com a sua própria realidade.

Contudo, colocava-se a questão de como desenvolver uma iniciativa, mesmo que legitimada por um centro de investigação, e a convite de uma associação local e com suporte municipal, que aparentemente iria contra a ideia que os moradores e as entidades responsáveis tinham para as práticas e para a imagem do bairro. Por parte das entidades responsáveis pela manutenção da higiene pública ou outra entidade camarária não seria possível obter uma autorização para a apropriação, naturalmente, e esta foi mais uma vertente desafiante do projeto, no confronto com a sua legitimação pelos atores locais. Nesse sentido, e assumindo a informalidade da intervenção, falou-se diretamente com os proprietários dos edifícios onde se pretendia colar as fotografias, os quais responderam de forma favorável à iniciativa lançada. Em sentido inverso foi a ação das entidades responsáveis pela fiscalização deste tipo de atividades no bairro (Polícia Municipal), as quais tentaram mesmo interromper a iniciativa, com a proibição da realização da intervenção e a ameaça de coima, durante a própria noite de "colagem-inauguração" do evento, mesmo decorrendo isto perante o relato atento do repórter da rádio $\operatorname{TSF}^{6}$ que acompanhava os autores 
durante a noite em que foram coladas as fotografias. Não obstante este percalço, e assumindo-o performativamente, face ao caráter de transgressão que a iniciativa queria explorar, foram coladas todas as fotografias pretendidas, "controlando" a supervisão dos agentes que circulavam pelo bairro. O momento da colagem das fotografias fica marcado por outras experiências e troca de ideias entre os autores e os transeuntes, que, perante a abordagem-ação, se confrontavam e interrogavam com a iniciativa, contribuindo inclusivamente para a reflexão quanto ao processo ideológico subjacente ou para dar conselhos de técnicas para ser mais difícil que a "polícia" ou outros utilizadores se apropriassem da foto. Num espaço público cada vez mais comodificado e mercantilizado pelas autoridades que o regulam (como à época se verificava frequentemente na praça Luís de Camões, à entrada do bairro, frequentemente cedida e apropriada para eventos comerciais e atividades culturais e políticas mais institucionais), o atuar numa fachada de um edifício, mesmo que com a autorização dos proprietários, revelou-se claramente uma experiência percebida como inapropriada e condenável pelas autoridades reguladoras (o que não é naturalmente alheio à política municipal de forte controlo da expansão da street art e em particular do graffiti na zona assumida à época, como pode ser constatado em Costa e Lopes 2014).

A intervenção não tinha um período fixo de permanência, mas o material efémero em que as fotografias estavam impressas e o modo como estavam coladas à parede não permitiam que se mantivessem por muito tempo. $\mathrm{O}$ facto de a intervenção entrar em disputa num espaço com regras próprias dentro da cidade, mesmo que ilegais, associadas à colagem de cartazes de divulgação de eventos culturais ou como tela para outro tipo de intervenções (por exemplo graffiti), contribuía para a efemeridade da iniciativa. Como consequência, algumas fotos desapareceram passadas algumas horas, enquanto outras, pelo contrário, se mantiveram por um longo período, não perdendo o seu caráter efémero, mas permanecendo e ampliando essa tensão. Foi o que aconteceu, por exemplo, com uma foto de um jovem pendurado numa janela em Brick Lane, Londres, que se manteve no local onde foi colada por mais de um ano. O desenrolar da ação em torno desta fotografia foi, aliás, bastante curioso e exemplar: o proprietário do imóvel (um estabelecimento de restauração) criou um sentido de forte identidade com a foto que o levava a mantê-la com um enorme orgulho, e isto não obstante as constantes apropriações que a parede e a foto sofriam por parte de graffiters; contudo, enquanto a parede envolvente era pintada por ele a cada novo tag, a fotografia manteve-se como um retrato da acumulação de layers de uma parede do Bairro Alto.

A efemeridade deste tipo de ações, que escolhem a cidade como pano de fundo, tem necessariamente de ser entendida e acolhida por quem desenvolve este tipo de intervenções. Elas estão na cidade e dialogam com ela, como algo efémero e que se encontra vulnerável à intervenção de outros utilizadores, 


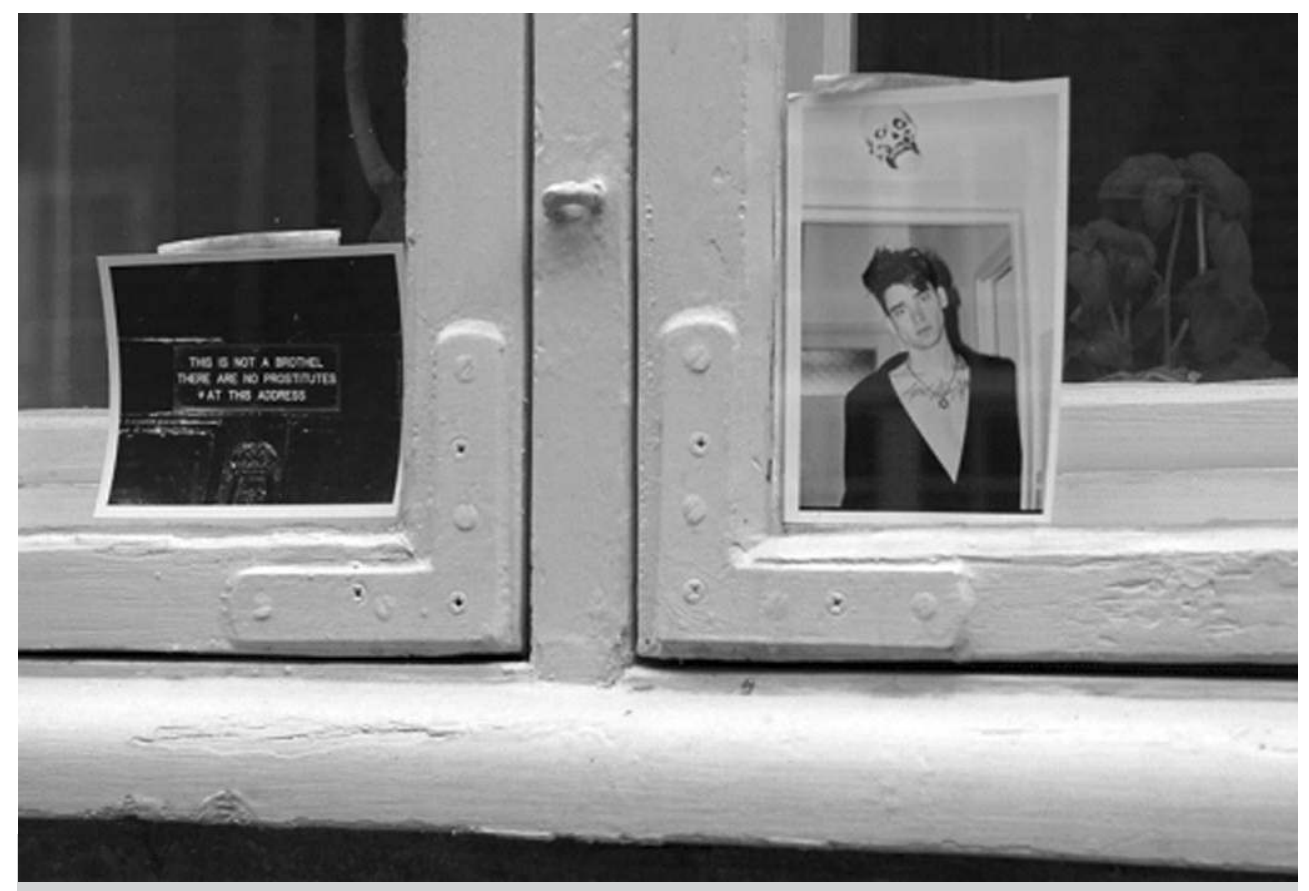

Figuras 10 a 17 - Intervenção "Bairros como nós” (Bairro Alto, dezembro de 2011).

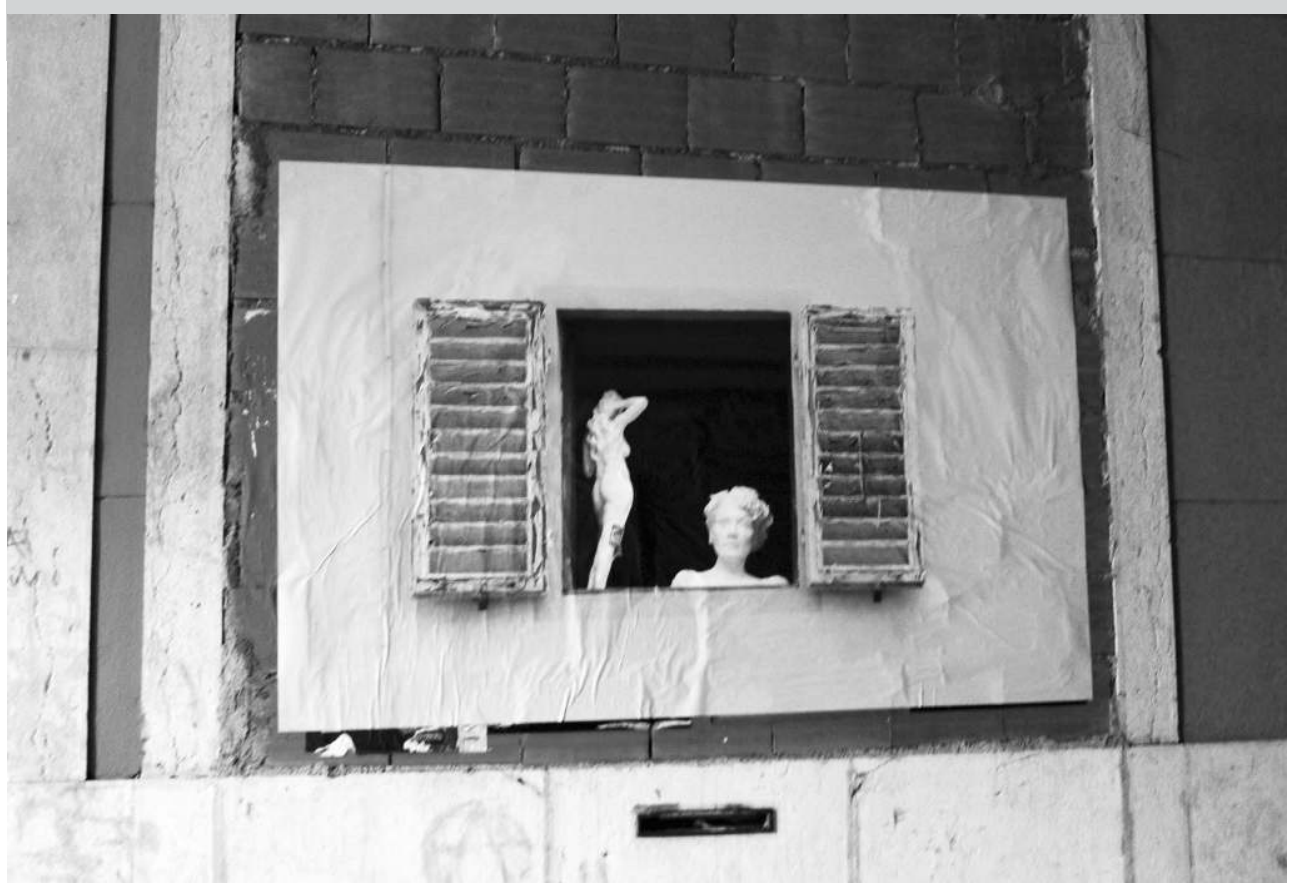




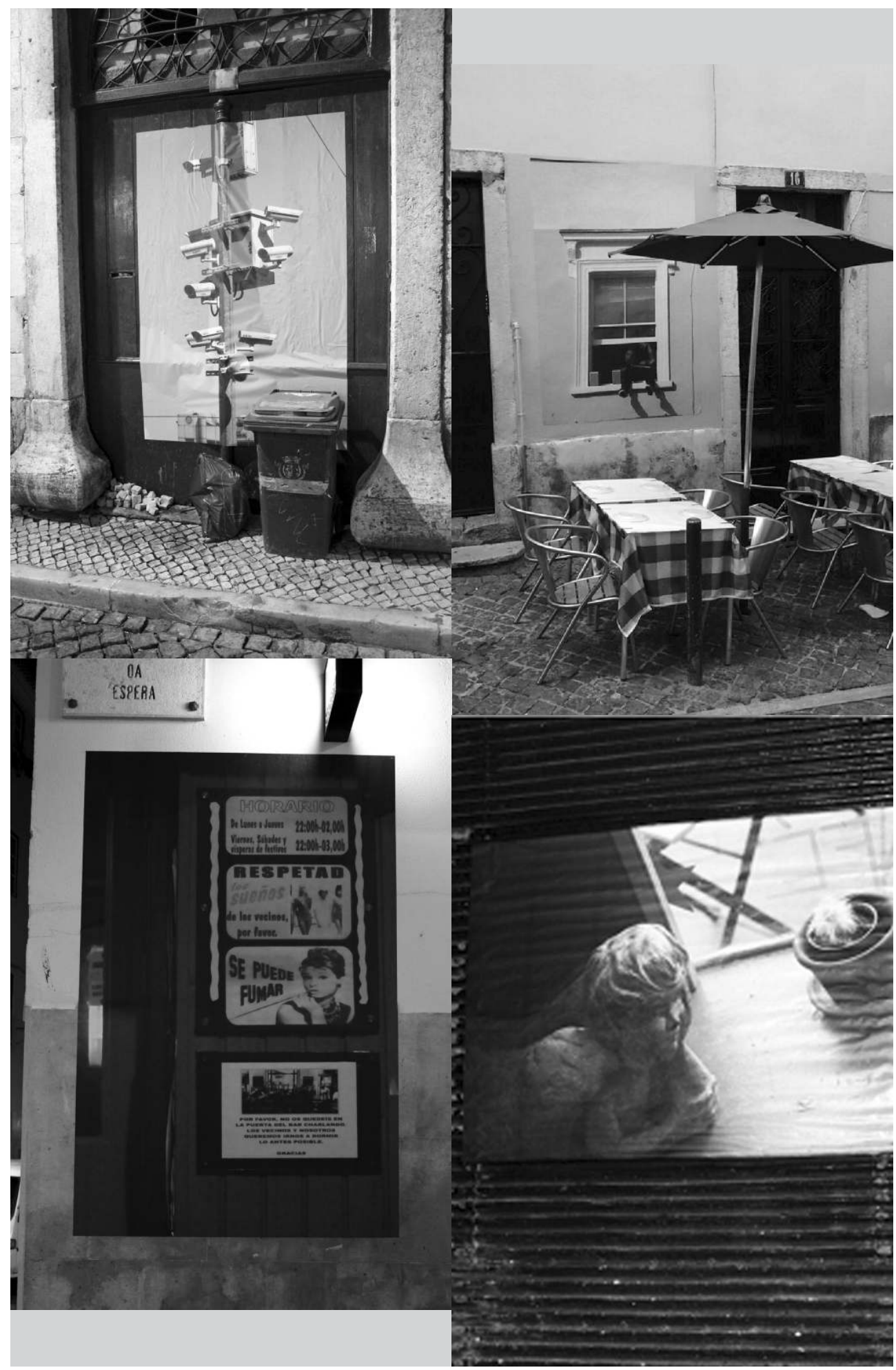



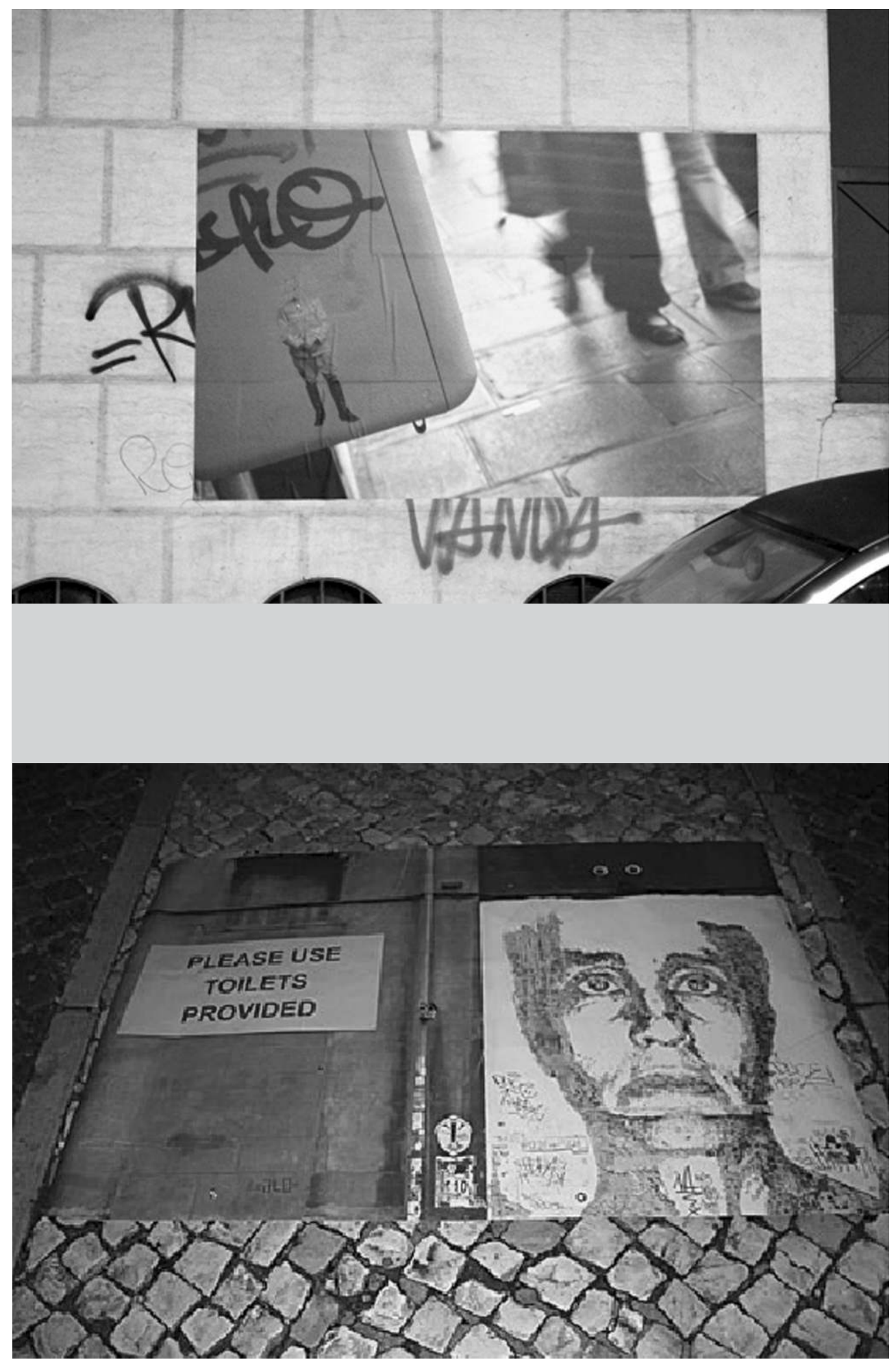
que se vão apropriando do objeto artístico, quer através da sua observação, alterando o cenário em que o "objeto" se insere, ou intervindo diretamente na peça.

Além de explorar os diversos aspetos artísticos e os limites entre público e privado, a exibição pretendia ainda criar, através do seu conteúdo específico, um sentido crítico nos observadores, que eram levados a pensar em acontecimentos diários do bairro a partir de uma perspetiva diferente. Os transeuntes e utilizadores do bairro eram confrontados, através destas imagens (sem explicação, que não uma discreta legenda com o local respetivo e os autores, geralmente não notada pelos seus observadores), com situações correntes e problemas com os quais lidam quotidianamente no "seu" bairro cultural - uma foto da Gràcia, em Barcelona, representava os protestos dos residentes contra os excessos da animação noturna, um conflito de uso que é comum neste tipo de bairros; uma outra foto, colada na janela de edifício "emparedado" na rua da Rosa, mostrava um rosto feminino "congelado a espreitar à janela", à imagem de muitos edifícios devolutos na cidade de Lisboa e que contribuem para uma cidade com menor vitalidade; um graffiti fotografado em Vila Madalena passou para a parede da travessa da Boa Hora; a panóplia de câmaras de vigilância da Praça Taksim (Beyoglu, Istambul) numa das entradas do bairro questionava os limites da privacidade de quem ali entra, sendo uma das zonas da cidade atualmente sujeita a videovigilância (e onde esse debate, na altura, fortemente se fazia sentir). Assim, criar um sentido crítico através da arte será outro dos aspetos fundamentais que as intervenções artísticas e este tipo de trabalhos académicos podem ter quando se desenvolvem na esfera pública, independentemente de serem, naturalmente, interpretados de maneira diferente pelos diferentes observadores. ${ }^{7}$

\section{"Beyond visible"}

Em dezembro de 2012 realizou-se a última intervenção em análise, intitulada "Beyond visible". ${ }^{8}$ Paralelamente a este evento, horas antes do início da intervenção propriamente dita, decorreu na Galeria Zé dos Bois (ZDB) um debate interdisciplinar subordinado ao mesmo tema, que contou com a presença de Pedro Costa, Ricardo Lopes, Mirian Tavares, Miguel Januário, António Louro, Joana Craveiro, Luís Balula e Pedro Botelho. Uma vez mais, os autores pretenderam criar pontes entre o meio criativo e a academia, quer através do local e contexto onde se desenvolveu a iniciativa, considerado um dos espaços mais legitimados do panorama artístico de Lisboa (associado a uma criação e a um

$7 \quad$ O graffiti e o stencil têm-se afirmando, aliás, como veículos muito ativos na contestação a algumas das restantes externalidades que afetam estes bairros, em Portugal - veja-se, por exemplo, o trabalho de Miguel Januário (aka “+-", ou "Mais Menos”).

8 Mais informação em < http://beyondvisibleba2012.blogspot.pt/>. 
público mais "erudito" e "alternativo", que se têm mantido longe da "mainstreamização" associada ao Bairro Alto), quer através do cruzamento de intervenientes académicos e artísticos no debate.

O happening, que seguia os conceitos explorados nas intervenções anteriores (como as relações entre espaço público e espaço privado, ou público e artwork), pretendia introduzir uma "sala de estar" num espaço expectante (neste caso um bar devoluto, entre usos, enquanto aguardava licenciamento para nova atividade no âmbito da restauração) na rua da Barroca, mesmo que apenas por uma noite, assumindo o conceito-chave de explorar a ideia dos diferentes layers de codificação existentes nos ambientes criativos, e nos bairros culturais em particular. Com efeito, estes são locais de diversidade por excelência, onde afluem e convivem diferentes pessoas, com vivências, estilos de vida, práticas e representações muito distintas, e onde se cruzam realidades múltiplas a diferentes ritmos, sem que, em muitos casos, os seus diferentes intervenientes se apercebam da sua coexistência, contribuindo esta multiplicidade para uma vitalidade constante às diferentes horas do dia ou nos diversos espaços destes bairros ( $c f$., por exemplo, Costa e Lopes 2015).

Assim, ao longo de uma noite, os transeuntes que caminhavam na rua eram convidados a entrar no espaço intervencionado e a construir a sua própria exposição, através de um percurso individual, o qual pretendia não ser de todo segregador de pessoas ou de práticas e em que cada visitante era confrontado com as suas autorrepresentações e com outras representações acerca do Bairro Alto, percecionando através da sua experiência individual de visita concreta as diferentes camadas de uso e de leitura do território.

Os visitantes eram atraídos por uma projeção (realizada a partir de casas de moradores nos prédios adjacentes) de várias fotos, que se sobrepunham na fachada oposta ao edifício onde decorria a intervenção, desenhando uma imagem difusa do bairro. Mais perto do local, as pessoas vislumbravam uma porta, por onde era possível entrar para uma "sala de estar escura", e uma outra, de onde saíam pessoas ao ritmo dos flashs das câmaras fotográficas.

A intervenção sugeria um percurso de exposição invertido. Começava com imagens de pessoas que já tinham sido fotografadas projetadas na parede da "sala de espera" onde recebiam lanternas ultravioleta (UV) para utilizar no interior do happening. Em seguida, entrava-se para a "caixa negra", e aí os participantes começavam a descobrir frases, através do percurso que estabelecessem individualmente, as quais tinham sido escritas com "tinta invisível" nas paredes interiores, e se tornavam visíveis à medida que uma dessas lanternas lhes era apontada. As frases tinham sido recolhidas anteriormente, no âmbito da preparação para este evento, através de entrevistas feitas no Bairro Alto a diferentes tipos de utilizadores, a diferentes horas do dia e em diferentes locais, e procuravam representar a (diversidade da) imagem da população acerca do bairro. A variedade de frases reproduzidas e a técnica utilizada permitiam 
que cada utilizador descobrisse coisas diversas e as interpretasse partindo de diferentes pontos de vista, tal como acontece com a perceção da cidade por parte dos seus utilizadores, conforme se constata em estudos clássicos, como os de Lynch (1960). Ao longo da exibição, os visitantes eram surpreendidos por outras intervenções artísticas, como um espaço de performance onde dois atores interagiam com os visitantes (um de cada vez num ambiente intimista de uma divisão escura) falando com eles sobre o Bairro Alto, ou como o "som de fundo" construído com sons recolhidos na zona (dando sequência ao trabalho desenvolvido em "Espaços liminares") que invadia o espaço saindo de um antigo poço que outrora tinha abastecido de água o edifício. ${ }^{9}$ No final da exibição, quatro fotógrafos tinham preparado uma réplica de um estúdio de fotografia onde fotografavam os participantes, que dessa forma passavam a fazer parte da intervenção artística, não só como espectador e elemento participante, mas também como objeto exibido (pois as suas fotografias, após serem recolhidas por estes fotógrafos, passavam a ser reproduzidas na instalação que iniciava o percurso expositivo). ${ }^{10}$ As fotografias tinham como ponto em comum o facto de estarem desfocadas, permitindo deste modo uma leitura enviesada para quem se apropriasse das imagens no início da intervenção, explorando-se aqui também as questões da videovigilância e hiperexposição que as sociedades contemporâneas apresentam na contemporaneidade, e com que o próprio bairro se confrontava.

Este percurso, provocando o confronto reflexivo das pessoas participantes com a diversidade de representações simbólicas sobre o bairro, com as suas próprias vivências e memórias, e com a multiplicidade de camadas de codificação e de abordagens patentes à vivência de um bairro cultural, permitiu identificar diversas situações de (maior ou menor nível de) reconhecimento individual nas representações sugeridas e questionar e interpelar de forma muito direta os sujeitos sobre a sua consciência acerca da centralidade deste espaço na cidade e acerca da(s) sua(s) diversidade(s).

\section{ALGUMAS NOTAS CONCLUSIVAS: INTERVENÇÕES ARTÍSTICAS EFÉMERAS, ABORDAGENS PARTICIPATIVAS NA INVESTIGAÇÃO E CONTRIBUTOS PARA O PLANEAMENTO URBANO}

Este artigo procurou discutir como uma abordagem de cariz etnográfico baseada em metodologias participativas pode contribuir para desvendar a complexidade do espaço urbano contemporâneo, através da análise de um

9 Performers: Nuno Antunes e Beatriz Henriques. Intervenção por marco (lê-se joão-pedro-joão); músicos: JPShelaq, Pedro Geraldes, João).

10 Performance fotográfica: Thiago Feitosa, Carolina Mota, Alexandre Abreu, Mariana Cortes. 


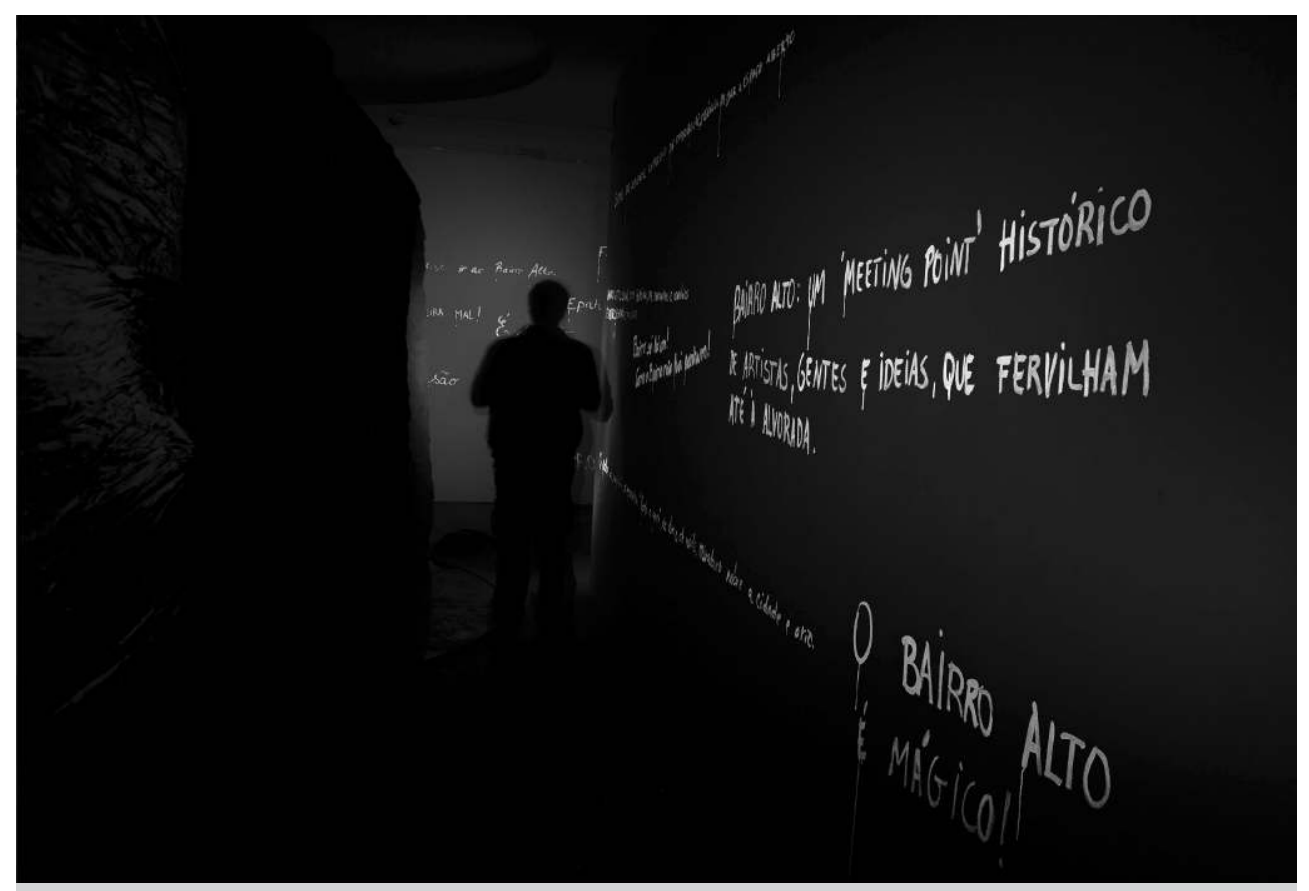

Figuras 18 a 25 - Intervenção "Beyond visible" (Bairro Alto, rua da Barroca, dezembro de 2012).

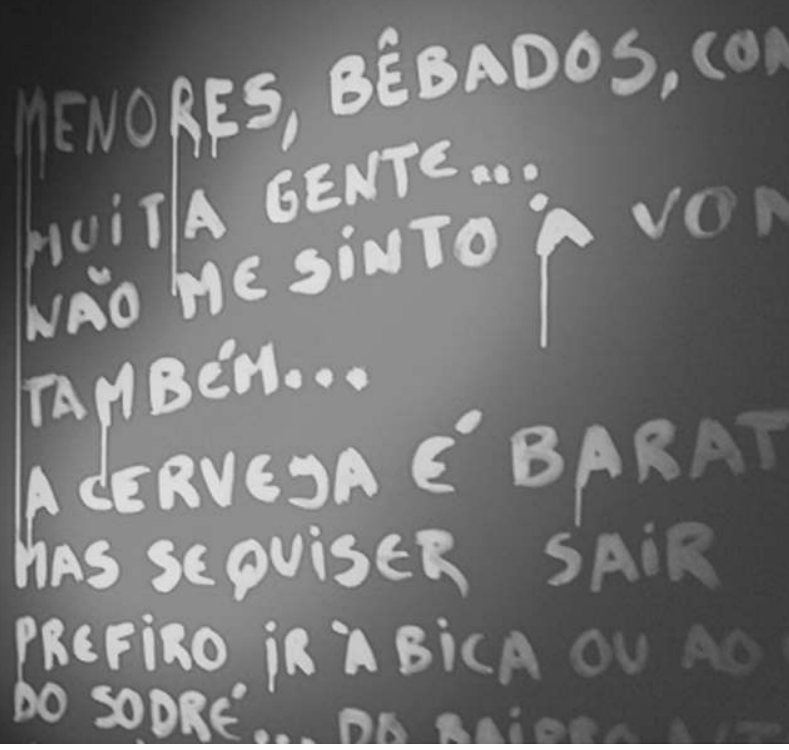




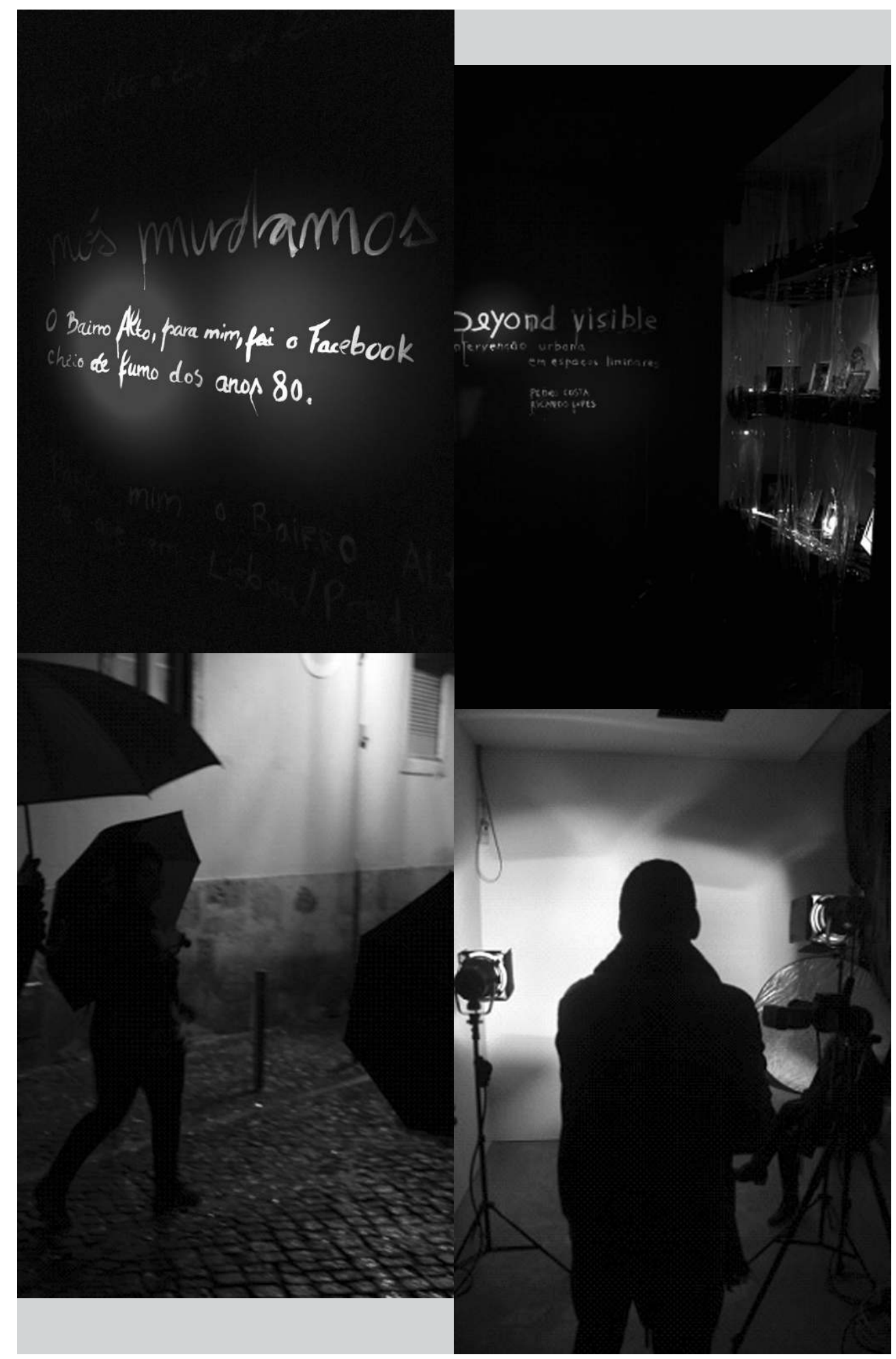


au lembro da noite de lá que eu ou Pembro das casintas com plores e roupa estendiala, com muitas

O BARRO FAZ ME SENTIR

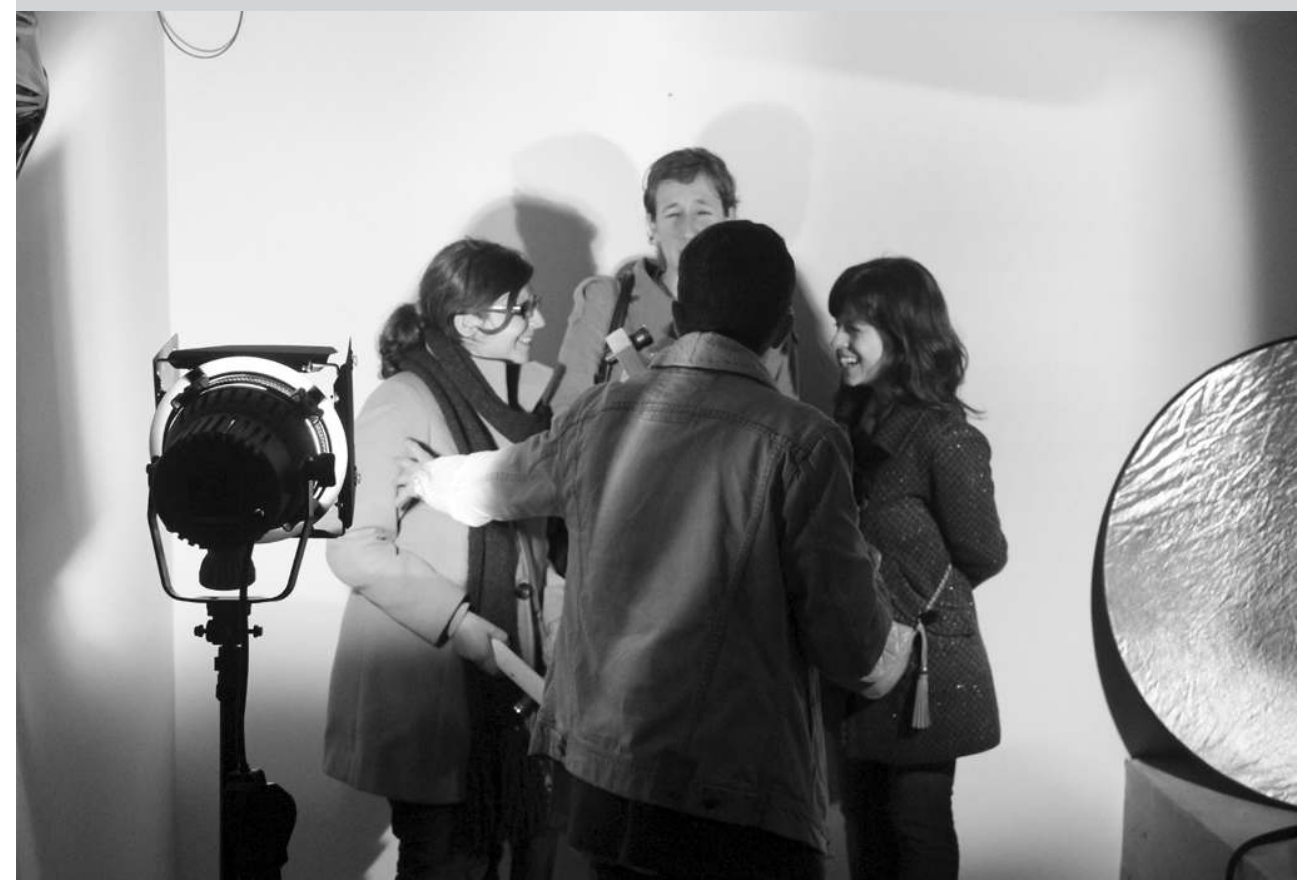


conjunto de três intervenções artísticas desenvolvidas pelos investigadores no principal bairro cultural de Lisboa, o Bairro Alto. Partiu-se do princípio de que as intervenções artísticas podem ser uma boa ferramenta a mobilizar no processo de investigação, no sentido de compreender as múltiplas camadas de usos, codificações e segregações que afetam estes espaços e de, em articulação com a comunidade local e os seus utilizadores, pensar em conjunto sobre os mecanismos que possam contribuir para a sua vitalidade quotidiana e, eventualmente, extrair daqui princípios para pensar a atuação dos planeadores sobre a cidade.

O objetivo primordial deste artigo não seria, portanto, o de dar conta dos efeitos das intervenções realizadas para o meio criativo respetivo, nem da relação destas intervenções com as dinâmicas urbanas e criativas neste território (a esse respeito, veja-se Costa e Lopes 2017), mas antes o de discutir o potencial do instrumental metodológico para o processo de pesquisa e para o planeamento urbano. E, com efeito, estas intervenções permitiram perceber como as abordagens ensaiadas apresentam um potencial muito interessante, e ainda bastante pouco explorado, para a produção de conhecimento científico neste campo e, para além disso, para o fazer numa lógica de comunicação estreita, biunívoca, com a comunidade que será o seu destinatário final.

Como acima se constata, as abordagens artísticas participativas utilizadas neste processo são essencialmente abordagens "hands-on", construindo o conhecimento através de metodologias de campo que envolvem, por um lado, a criação estética e, por outro, uma cooperação entre "pesquisadores" e "sujeitos da pesquisa", e que mobilizam ativamente estas duas vertentes para a construção e verificação dos resultados do processo de investigação. A deslocação do foco do investigador para o objeto de investigação, assumindo uma cooperação ao mesmo nível entre os dois polos desta relação, permite desafiar e questionar constantemente as ferramentas conceptuais e analíticas do investigador, enriquecendo o processo de pesquisa.

Neste quadro, a criação/fruição artística (vista através dos olhos desta cooperação entre investigador e objeto) permite explorar a experienciação urbana e as causas e consequências das dinâmicas urbanas associadas a uma determinada intervenção urbana, de forma inovadora, procurando resultados que seriam inatingíveis com abordagens mais clássicas.

Foi isso que foi feito no Bairro Alto através destas três experiências, estabelecendo "novos" diálogos com um bairro cultural, através da intervenção urbana. Foram exploradas abordagens participativas baseadas em diferentes disciplinas artísticas, permitindo testar por diversas vias um conjunto de ideias em relação às lógicas de apropriação do espaço, às dinâmicas de liminaridade e de conflito verificadas, e à capacidade de vitalização urbana latente neste território. Por um lado, estas intervenções permitiram-nos recolher informação extra, que muitas vezes ficaria oculta em processos assentes em metodologias 
mais convencionais, gerando informação preciosa, complementar à mobilizada por outras fontes e recursos que têm sido aplicados em paralelo pelos autores neste programa de investigação. Por outro lado, estas abordagens permitiram-nos devolver resultados à comunidade, confrontando-a em diversos momentos com alguns dos resultados da pesquisa (e voltar a recolher nova informação, a cada novo confronto), num processo interativo que estamos convictos de que reforça em muito o processo de (co)criação de conhecimento, bem como as boas práticas de disseminação dos resultados da produção científica para a comunidade.

Em termos mais concretos, o trabalho efetuado permitiu-nos aprofundar, conceptual e empiricamente, a relação entre (i) os pressupostos da vitalidade urbana, (ii) as dinâmicas de conflito e as lógicas de informalidade, e (iii) os mecanismos de liminaridade e de distinção no campo cultural, para o caso concreto do Bairro Alto, no âmbito do programa de pesquisa que temos vindo a desenvolver sobre a territorialização das dinâmicas criativas contemporâneas. Fica claro o potencial das abordagens participativas artísticas para esta análise, e em particular a importância da intervenção artística de microescala, ou mais efémera, muitas vezes assente em dinâmicas transitórias ou de informalidade. Partindo muitas vezes de uma base "informal" ou até "ilegal", estes projetos surgem na cidade com a mesma facilidade com que desaparecem, permitindo, no entanto, uma experimentação de conceitos que seriam mais difíceis de testar e discutir através de "obras" mais perenes, e levantando novos desafios e potencialidades aos processos de planeamento urbano. Em paralelo, estas abordagens permitem equacionar o papel deste tipo de intervenções nos processos de desenvolvimento territorial, evidenciando, por um lado, a complexidade dos mecanismos a elas inerentes (implicando a gestão de atributos simbólicos delas decorrentes, para os artistas, para as intervenções, para os lugares, bem como a gestão da rede intensa de motivações, interesses e conflitos de uso que lhes estão inerentes) e, por outro lado, o potencial e possibilidades de utilização (e de instrumentalização) em processos de desenvolvimento ( $c f$. Costa e Lopes 2017, para mais detalhes em relação a estes aspetos).

De forma mais genérica, um entendimento mais profundo das dinâmicas criativas de base territorial aqui analisadas, por contraste com a "agenda criativa" que tem dominado muita da análise académica e do policy making neste campo nos anos mais recentes (ver, por exemplo, Scott 2006, 2014), sugeriria pensar uma nova agenda do planeamento para lidar com as dinâmicas criativas urbanas e os bairros culturais. Não temos aqui essa ambição, mas três noções parecem-nos centrais a retirar da reflexão aqui encetada: (i) a importância da atenção a estas questões (informalidade, conflito, liminaridade, etc.), quando lidando com as dinâmicas criativas; (ii) a relevância de perceber as especificidades de cada sistema territorial, dos seus atores, dos recursos locais, dos mecanismos de governança; e (iii) a importância da abertura à informalidade, 
de criação de espaços para a liminaridade, e de menos institucionalização (cf. Costa e Lopes 2017).

Para cada um destes aspetos (e por causa de cada um deles...), o recurso a este tipo de abordagens metodológicas na investigação abre-nos um campo que importará continuar a explorar no futuro. Elas dão-nos instrumentos que nos permitem testar e aprofundar analiticamente estas dimensões mais intangíveis e territorializadas da vitalização urbana, seja no campo dos efeitos materiais que estas intervenções proporcionam, seja no campo do simbólico e dos efeitos de intermediação e gatekeeping que elas produzem, por mais efémeras ou permanentes que sejam. Mas elas dão-nos igualmente, por outro lado, um poder de trabalhar a reflexividade, a consciencialização e a capacitação das diversas comunidades envolvidas, aos mais diversos níveis, através de processos de cocriação e acumulação de conhecimento, que não seriam possíveis através de métodos de pesquisa mais convencionais. Por agora fica a intenção de continuar certamente a explorar o potencial heurístico deste tipo de abordagens e de continuar a abrir pontes entre os processos de criação artística e os mecanismos de investigação científica, bem como a vontade de continuar a promover o envolvimento da comunidade em processos reflexivos de construção de conhecimento, não apenas como recetores e destinatários finais do output da investigação feita por "cientistas", mas como cocriadores e correceptores (e cointérpretes) do conhecimento produzido através destas dinâmicas de investigação-ação sobre a realidade.

\section{BIBLIOGRAFIA}

BECKER, Howard S., 1982, Art Worlds. Berkeley, University of California Press.

BELL, David, e Mark JAYNE (orgs.), 2004, City of Quarters: Urban Villages in the Contemporary City. Aldershot, Ashgate.

BORGES, Vera, e Pedro COSTA (orgs.), 2012, Criatividade e Instituições: Novos Desafios à Vida dos Artistas e Profissionais da Cultura. Lisboa, Imprensa de Ciências Sociais.

CAMPOS, Ricardo, 2007, Pintando a Cidade: Uma Abordagem Antropológica ao Graffiti Urbano.

Lisboa, Universidade Aberta, tese de doutoramento em Antropologia Visual.

CAVES, Richard E., 2002, Creative Industries: Contracts between Art and Commerce. Cambridge, MA, Harvard University Press.

COOKE, Philip, e Luciana LAZZERETTI (orgs.), 2008, Creative Cities, Cultural Clusters and Local Development. Cheltenham, Edward Elgar.

COSTA, Pedro, 2007, A Cultura em Lisboa: Competitividade e Desenvolvimento Territorial. Lisboa,

Imprensa de Ciências Sociais. 
COSTA, Pedro, 2008, "Creativity, innovation and territorial agglomeration in cultural activities: the roots of the creative city", in P. Cooke e L. Lazzeretti (orgs.), Creative Cities, Cultural Clusters and Local Development. Cheltenham, Edward Elgar, 183-210.

COSTA, Pedro, 2009, Bairro Alto - Chiado: Efeitos de Meio e Desenvolvimento Sustentável de Um Bairro Cultural. Lisboa, DPPC/Câmara Municipal de Lisboa.

COSTA, Pedro, 2012, "Gatekeeping processes, reputation building and creative milieus: evidence from case studies in Lisboa, Barcelona and São Paulo", em L. Lazzeretti (org.), Creative Industries and Innovation in Europe: Concepts, Measures and Comparative Case Studies. Londres, Routledge, 286-306.

COSTA, Pedro, 2013, "Bairro Alto revisited: reputation and symbolic assets as drivers for sustainable innovation in the city", Dinâmia'CET-IUL Working Papers, 2013/14, DOI: 10.7749/dinamiacet-iul.wp.2013.14.

COSTA, Pedro, 2015, "Cultural districts and the evolving geographies of underground music scenes: dealing with Bairro Alto's mainstreaming”, em P. Guerra e T. Moreira (orgs.), Keep it Simple, Make it Fast! An Approach to Underground Music Scenes. Porto, Faculdade de Letras da Universidade do Porto, 591-605.

COSTA, Pedro, et al., 2008, "On 'creative cities' governance models: a comparative approach", The Service Industries Journal, 28 (3): 393-413, DOI: 10.1080/02642060701856282.

COSTA, Pedro, e Ricardo LOPES, 2011 , "Padrões locativos intrametropolitanos do cluster da cultura: a territorialidade das actividades culturais em Lisboa, Barcelona e São Paulo", REDIGE - Revista de Design, Inovação e Gestão Estratégica, 2 (2): 196-244.

COSTA, Pedro, e Ricardo LOPES, 2013, "Urban design, public space and creative milieus: an international comparative approach to informal dynamics in cultural districts”, Cidades, Comunidades e Territórios, 26: 40-66.

COSTA, Pedro, e Ricardo LOPES, 2014, "Is street art institutionalizable? Challenges to an alternative urban policy in Lisbon”, Dinâmia'CET-IUL Working Papers, 2014/08, DOI: 10.7749/dinamiacet-iul.wp.2014.08.

COSTA, Pedro, e Ricardo LOPES, 2015, "Urban design, public space and the dynamics of creative milieux: a photographic approach to Bairro Alto (Lisbon), Gràcia (Barcelona) and Vila Madalena (São Paulo)”, Journal of Urban Design, 20 (1): 28-51.

COSTA, Pedro, e Ricardo LOPES, 2016, "Dos dois lados do espelho: diálogos com um bairro cultural através da intervenção urbana”, Dinâmia'CET-IUL Working Papers, 2016/04, DOI: 10.15847/dinamiacet-iul.wp.2016.04.

COSTA, Pedro, e Ricardo LOPES, 2017, "Artistic urban interventions, informality and public sphere: Research insights from three ephemeral urban appropriations on a cultural district", Portuguese Journal of Social Science, 16 (3): 323-342.

COSTA, Pedro, Bruno VASCONCELOS, e Gustavo SUGAHARA, 2011 , "The urban milieu and the genesis of creativity in cultural activities: an introductory framework for the analysis of urban creative dynamics", Cidades, Comunidades e Territórios, 22: 3-21.

DiMAGGIO, Paul, 1987, "Classification in art", American Sociological Review, 52: 440-455.

LOPES, Ricardo, 2012, Intervenções Artísticas Efémeras e Apropriação de Espaço Público em Contextos Urbanos Informais: Análise de Cinco "Bairros Criativos": Bairro Alto e Cais do Sodré, Gràcia, Vila Madalena, Brick Lane e Kreuzberg SO36. Lisboa, ISCTE-IUL, tese de mestrado em Arquitetura.

LOPES, Ricardo, 2015, "Do Bairro Alto ao Cais do Sodré: criatividade, informalidade e recomposição física, social, funcional e económica”, Revista Rossio: Estudos de Lisboa, 4: 80-93. 
LYNCH, Kevin, 1960, The Image of the City. Cambridge, MA, The MIT Press.

O'CONNOR, Justin, e Derek WYNNE (orgs.), 1996, From the Margins to the Centre: Cultural Production and Consumption in the Post-Industrial City. Aldershot, Arena.

SCOTT, Allen J., 2000, The Cultural Economy of Cities. Nova Deli, Londres e Thousand Oaks, Sage.

SCOTT, Allen J., 2006, "Creative cities: conceptual issues and policy questions", Journal of Urban Affairs, 28 (1): 1-17, DOI: 10.111 l/j.0735-2166.2006.00256.x.

SCOTT, Allen J., 2014, "Beyond the creative city: cognitive-cultural capitalism and the new urbanism", Regional Studies, 48 (4): 565-578.

TRAQUINO, Marta, 2010, A Construção do Lugar pela Arte Contemporânea. Ribeirão, Húmus. 